San Jose State University

SJSU ScholarWorks

Master's Theses

Master's Theses and Graduate Research

1993

\title{
The school nurse role as perceived by elementary and junior high school teachers
}

Willempje V. Kremer

San Jose State University

Follow this and additional works at: https://scholarworks.sjsu.edu/etd_theses

\section{Recommended Citation}

Kremer, Willempje V., "The school nurse role as perceived by elementary and junior high school teachers" (1993). Master's Theses. 691. DOI: https://doi.org/10.31979/etd.tz39-2b3v

https://scholarworks.sjsu.edu/etd_theses/691

This Thesis is brought to you for free and open access by the Master's Theses and Graduate Research at SJSU ScholarWorks. It has been accepted for inclusion in Master's Theses by an authorized administrator of SJSU ScholarWorks. For more information, please contact scholarworks@sjsu.edu. 


\section{INFORMATION TO USERS}

This manuscript has been reproduced from the microfilm master. UMI films the text directly from the original or copy submitted. Thus, some thesis and dissertation copies are in typewriter face, while others may be from any type of computer printer.

The quality of this reproduction is dependent upon the quality of the copy submitted. Broken or indistinct print, colored or poor quality illustrations and photographs, print bleedthrough, substandard margins, and improper alignment can adversely affect reproduction.

In the unlikely event that the author did not send UMI a complete manuscript and there are missing pages, these will be noted. Also, if unauthorized copyright material had to be removed, a note will indicate the deletion.

Oversize materials (e.g., maps, drawings, charts) are reproduced by sectioning the original, beginning at the upper left-hand corner and continuing from left to right in equal sections with small overlaps. Each original is also photographed in one exposure and is included in reduced form at the back of the book.

Photographs included in the original manuscript have becil reproduced xerographically in this copy. Higher quality 6" x 9" black and white photographic prints are available for any photographs or illustrations appearing in this copy for an additional charge. Contact UMI directly to order.

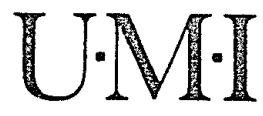

University Microfilms International

A Bell \& Howell Information Company 

Order Number $\mathbf{1 8 5 6 4 7 4}$

The school nurse role as perceived by elementary and junior high school teachers

Kremer, Willempje V., M.S.

San Jose State University, 1993

Copyright (c)1993 by Kremer, Willempje V. All rights reserved. 



\title{
THE SCHOOL NURSE ROLE AS PERCEIVED BY ELEMENTARY AND JUNIOR HIGH SCHOOL TEACHERS
}

\author{
A Thesis \\ Presented to \\ The Faculty of the School of Nursing \\ San Jose State University \\ In Partial Fulfillment \\ of the Reguirements for the Degree \\ Master of Science
}

By

Willempje V. Kremer

December, 1993 
(C) 1993

Willempje V. Kremer

ALL RIGHTS RESERVED 
APPROVED FOR THE SCHOOL OF NURSING

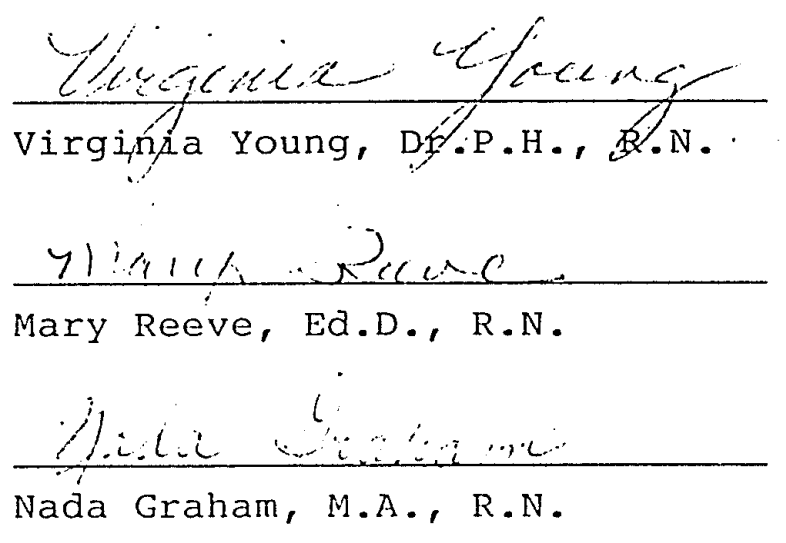

APPROVED FOR THE UNIVERSITY In. Ire Ttewrondownthi 
ABSTRACT

THE SCHOOL NURSE ROLE AS PERCEIVED BY ELEMENTARY AND JUNIOR

$$
\text { HIGH SCHOOL TEACHERS }
$$

By Willempje V. Kremer

The purpose of this study was to determine which components of the school nurse role are perceived as most important by elementary and junior high school teachers. A descriptive survey was used. The School Nurse Service Data Collection Tool was used to obtain data from teachers $(\underline{N}=242)$. Frequencies and mean values were calculated to determine which services were viewed as most important for school nurses to provide: School nurse services were categorized according to the California Commission on Teacher Credentialing Role Concepts of the Standards of Quality and Effectiveness for Developing and Evaluating Programs of Professional School Nurse Preparation in California. Services considered most important were vision and hearing screening, health problems list, emergency care, health liaison, and investigating health concerns. These services related to the role of care provider, communicator, and planner/coordinator. 
ACKNOWLEDGEMENTS

To my husband, Hans, and daughters, Saskia and Taryn, for their interest, understanding and support;

to the teachers, secretary, and school nurses for their assistance with the data collection;

and to my readers

Virginia Young, Mary Reeve, and Nada Graham

, for their time and encouragement. 
LIST OF TABLES........................... vii

LIST OF FIGURES......................... viii

Chapter

1. INTRODUCTION....................... 1

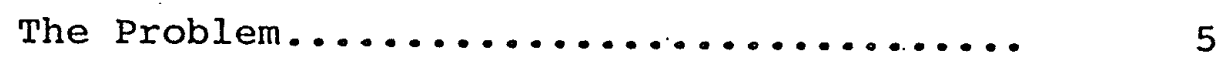

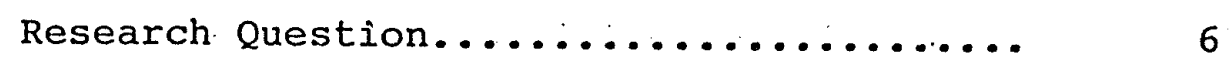

Purpose of the study.................. 6

Significance of the study............... 7

Definitions of Terms................ 8

Research Design..................... 9

2. CONCEPTUAL FRAMEWORK AND LITERATURE REVIEW 12

Conceptional Framework............... 12

Review of the Literature............. 16

Related studies..................... 18

summary......................... 22

3. RESEARCH DESIGN AND METHODOLOGY.......... 24

Research Design.................... 24

Setting and sample................. 24

Human Subjects Approval............. 25

Data Collection Tool................. 25

Data Collection Procedures............. 26

Analysis Procedures................. 27 
4. ANALYSIS AND INTERPRETATION OF DATA....... 28

Introduction.................... 28

Characteristics of the Sampie........... 28

Frequency and Mean of Responses......... 30

Responses to the Open-Ended Questions...... 39

Summary......................... 42

5. CONCLUSIONS AND RECOMMENDATIONS.......... 43

Summary of study.................... 43

Conclusions........................ 43

Limitations...................... 47

Recommendations for Further Research...... 48

Recommendations for School Nursing Practice 50

REFERENCES............................. 52

APPENDICES............................... 59

A. Cover/Consent Letter.............. 59

B. Questionnaire for study............. 61

C. Permission to use Questionnaire ...... 66

D. San Jose State University Institutional

Review Board Approval.............. 69

E. Agency Consent Letter............. 72 


\section{LIST OF TABLES}

Page

Table

1. Demographic Characteristics of Sample....... 29

2. Frequency and Percentage of Response to Items 33

3. Items 1-44 Rank Ordered by Mean (M) Score.... 36

4. Comparison of Means of Role Concepts

in 2 studies....................... 


\section{LIST OF FIGURES}

Page

Figure

1. Model of School Nurse Role Concepts.......... 14 


\section{Chapter 1}

INTRODUCTION

The ultimate aim of school health services is to support and enhance education (Zanga \& Oda, 1987). In the United States such services were initiated in 1884 in Boston and consisted of routine inspections and exclusion of students with communicable diseases from the school. In many instances the children stayed out of school far longer than needed because follow-up was not a part of the process.

Lillian Wald, developer of the Henry street settlement in New York City, successfully negotiated the first school nurse position in that city in 1903. This first school nurse, Lina Rodgers, mainly focused on prevention and control of communicable diseases but included follow-up services as well (Thurber, Berry, \& Cameron, 1991; Wold, $1981)$

The efforts of this school nurse pioneer were so successful that shortly thereafter more "school nurses" were hired and later the school nurse services were incorporated into school health programs throughout the United states (White, 1985). These early school nurses were basically public health nurses who followed the students from the schools into their homes. As time passed, the focus of the school nurses widened to include 
identification and treatment of physical defects and promotion of healthful lifestyles among students (Zanga \& Oda, 1987). Additional public health nurses were hired by the Board of Education to work as school nurses. Circa 1924 school nurses began to incorporate health education into their health services program (Regan, 1976). From the early 1920s to the late 1940s, the emphasis was on health teaching and health care services.. Although these school nurses were known in certain areas as "school nurse teachers" or "teacher nurses," they lacked the educational background to be effective educators in the school environment. As a result, teachers assumed responsibility for health education in the classroom. During the 1950s and 1960s the role of school nurses further expanded to include counseling, coordination of community health services, and physical assessments (Johnson-Russel \& Anema, 1989; White, 1985). The political and economic climate of this period allowed the addition to the school staff of other support services personnel such as social workers, psychologists, and health educators. By the late 1960 s school districts were faced with reduced budgets and typically cut services that generated the least opposition from the public and/or that were not well documented and valued--such as school nurse services. In an attempt to be more accessable to and thus better serve adolescents, the first school-based health clinic 
opened in Dallas in 1970 to provide health care for this population (Stone \& Perry, 1990). Shortly thereafter, additional clinics were opened on or adjacent to junior and senior high school campuses to serve adolescents. These clinics were meeting the needs of the adolescent population since it was the "....only segment of the population to experience an increase in mortality rates over the past 20 years, with a shift from deaths due to disease to those related to social, environmental, and behavioral factors" (Council on Scientific Affairs, 1990, p. 89). Currently, many school-based health clinics serve elementary students as well.

In 1977, Public Law 94-142 was enacted (Lerner, 1989). It provided for a free and appropriate education for all handicapped children and youth aged three through twenty-one years. As a result, there was a growing awareness of the need for increased complex clinical nursing skills that led to the creation of the school nurse practitioner (SNP) and the school clinical nurse specialist (SCNS). Besides assessing health status and providing health care, the SNP integrates health care and fosters health education (Johnson-Russell \& Anema, 1989). Similarly, the SCNS furnishes comprehensive care as an expert practitioner, educator, researcher, and consultant (Hamric \& Spross, 1989, p. 10).

Financial constraints continued to plague school 
districts throughout the $1980 \mathrm{~s}$ and into the $1990 \mathrm{~s}$.

Elimination of school nurse positions was far from rare; some school districts completely abolished school nurse services. In 1992, approximately 5-108 of school nurse positions were lost in the state of California according to V. Young-Cureton, former Vice. President California School Nurses Organization (personal communication, May 3, 1993). Some districts resorted to contracting with other health care providers or with county health services for the provision of state mandated services. The majority of the districts in California, however, opted to maintain part or all of their school nurse services.

Today, meeting the complex health needs of students and managing communicable diseases presents a major challenge to the nation's 33,000 school nurses (Johnson-Russell \& Anema, 1989). Less than 508 of all American 2-year-old children are fully immunized; in 1990, 30,000 cases of measles, mumps, and whooping cough were reported (Igoe \& Ciordano, 1992). In addition, many students have a myriad of physical and emotional problems which can be attributed to recent societal changes (Young-Cureton \& Epstein, 1991).

Over time, therefore, school health needs changed, and the role of school nurses has been redefined and expanded in response to health problems of pupils, their families, and communities as "Nursing can no more remain 
static than any other aspect of nursing or education" (Bryan, 1973, p. 2). Responsibilities of school nurses now include assessment and management of the multifaceted' physical, emotional, and social health needs of students and their families (Ely \& Crowell, 1987; Miller, 1990). This expansion of the role of school nurses led to "role confusion" when other support staff joined school personnel in the 1950 s and 1960 s to provide services previously offered by school nurses (White, 1985). The boundaries of school nurses' responsibilities became vague to school nurses as well as to teachers and other school staff. Consequently, school nurses need to clarify their role, agree on their role, and set priorities for school nursing.

The Problem

School nursing remains the area in nursing most difficult to define (Oda, 1991). School nurses continue to encounter problems with misinterpretations of their role, unsupportive administrators, and lack of cooperation from teachers (Cassel, 1993; McNab \& Canida, 1980; Quick, 1993; Resnick, Blum, \& Hector, 1980; Thurber et al., 1991; White, 1985; Young \& Quick, 1991). Although the state of California clearly specifies the requirements for the training and education of school nurses, the role and responsibilities of school nurses are not well defined (Nehls, 1989). Additional factors contributing to the 
lack of role delineation are the disparate educational preparation among states (Brajkovich \& Madison, 1986; Edwards \& Cowell, 1985; Marriner, 1971), lack of uniformity of criteria for certification of school nursing nationally, and the fact that standards of care for school nursing are not widely known or practiced (Wold, 1981).

Furthermore, standards developed and revised by the California Commission on Teacher Credentialing (CTC 1.988, 1989) have been unsuccessful in alleviating the confusion; the guidelines are all encompassing and priorities for practice are not delineated. In addition, school nursing is practiced in non-medical settings in which school nurses fill the hiatus between the complex education and health systems (Oda, 1991; Regan, 1976; Ridge, 1980).

Investigating the teachers' perceptions of the school nurse role may offer clarity and promote understanding, cooperation, and collaboration between school nurses and teachers. A close and effective working relationship between these professionals is essential in enabling students to reach their potentials (Hawes, 1989).

\section{Research Question}

The research question for this study was: What services do elementary and junior high school teachers view as most important for the school nurse to provide? "'

Purpose of the study

Expectations of services to be provided by school 
nurses vary widely, not only among school districts and different states, but even among staff members within a single school district. Limited time, facilities, and resources' prohibit delivery of all needed and expected services--some of which do not require the attention of a professional nurse. There is a widespread need for improved understanding of the school nurse's role by parents, administrators, and teachers (Cassel, 1993; Nehls, 1989; Resnick et al., 1980; Sadik, 1992). Teachers are significant consumers of school nurse services and frequently instrumental in securing such services for their pupils. Therefore, educators were selected as subjects for this replication study.

The study was undertaken to determine which components of the school nurse role are perceived as most important by elementary and junior high school teachers. The information obtained builds on previous research conducted by Sadik in 1992. The findings are valuable in clarifying the teachers' perceptions of the school nurse role. Significance of the study Conflict and confusion about the school nurse role have posed a problem to school nurses and educators for over thirty years (White, 1985). Combined with the current economic climate in California, where drastic reductions in funding for public schools have resulted in all-time high student-nurse ratios, priority setting is an absolute 
necessity for the school nurse. In order to perform duties as effectively and efficiently as possible, and to encourage teamwork between the school nurse and educators, school nurse priorities should be congruent with those of the teaching faculty.

The results of this study can lead to a clearer definition of the school nurse role which, in turn, would generate more research for the purpose of documenting the value of school nurse interventions (Cassel, 1993). Findings will be useful to school nurses in making decisions on the type of services to be delivered. Elucidation of the school nurse role will increase the school nurses' as well as the teachers' understanding of the role, and thus enhance cooperation between these professionals. Not only teachers and school nurses, but equally or more importantly, students will be beneficiaries of such collaboration.

\section{Definition of Terms}

1. Elementary school is a public school for students in Kindergarten through Grade 6. Pre-school programs may be offered at the elementary site as well.

2. Junior high school is a public school offering classes to students in Grades 7 and 8 .

3. School nurse is a person employed by the school district to provide health related services in the school district. In California, school nurses are required to 
be Registered Nurses, to hold a Bachelor's degree, and have knowledge of public health/community nursing. In addition, a California School Nurse Credential issued by . the state of California CTC is required.

4. School nurse services are health related services that are provided by the school nurse as described in the school nurse job description.

5. Teacher is a person employed by the school district. to provide classroom instruction. Teachers in California must possess a teaching credential issued by the California CTC.

Research Design

This study was a partial replication of research conducted in a San Francisco Bay Area school district by Sadik in 1992. In this study, a non-experimental descriptive survey design was also utilized. Questionnaires were distributed by school nurses to a convenience sample of all elementary and junior high school teachers of another San Francisco Bay Area school district. Participation was voluntary and responses were anonymous. Each questionnaire was accompanied by a cover/consent letter (see Appendix A) containing an explanation of the purpose of the study and instructions for participation. An envelope for return of the survey to the school nurse's mailbox within 5 days was also included.

The questionnaire. (see Appendix B) used in this study 
was the modified version of the school Nurse service (SNS) Data Collection Tool designed by Nehls in 1989 and modified by Palmer and Young in 1991 (personal communication, October 27, 1992). The instrument consists of 44 items listing school nurse services to be ranked from very important to not important on a 4-point Likert scale. Question 45 asks the subjects to list any other services omitted but deemed important. Finally, there is a brief section with questions to determine demographic information. The questions were evaluated for clarity, validity, and completeness by nine school. nurse experts. The tool was pilot-tested on a small group of students, parents, and teachers (Cassel, 1993; Palmer, 1993; Sadik, 1992). Although no statistical tests were carried out to measure reliability and the tool was never used on the same group twice, close results were obtained with use of the tool in 4 studies. with different groups of teachers. Using the above mentioned tool in this study, data were obtained from 242 teachers. A descriptive statistical analysis was performed on the data. Frequencies, percentages, and mean values were determined. Responses were rank ordered according to importance based on the mean $(\underline{M})$. Teachers indicated whether they considered services very important, important, somewhat important, or not important to be provided by the school nurse. The findings of this study will increase the existing body 
of knowledge, understanding of and agreement on the school nurse role, and efficiency of the school nurse through improved priority setting. 


\section{Chapter 2}

\section{CONCEPTUAL FRAMEWORK AND IITERATURE REVIEW}

Conceptual Framework

A conceptual framework provides a guide for school nursing practice. It assists school nurses in planning, performing, and evaluating school health services. In research it helps determine the boundaries of the study and specifies who and what will and will not be studied, according to saylor (personal communication, september $30,1992)$.

Two frameworks for school nursing practice were designed by Wold and Dagg (1978), and Oda.(1981). Oda's framework for school nursing is composed of the areas of health supervision, health counseling, and health education. Health supervision includes health assesments, emergency care, and health deficit identification. Health counseling involves advising students regarding health behaviors, interpreting health information, and making recommendations regarding health conditions. Health education encompasses planning, promoting, and implementing health instruction. Wold and Dagg's conceptual framework for school nursing consists of a cluster of concepts: (1) public health; (2) adaptation; (3) helping relations; (4) tools; and (5) systematic process. The applicability of "public. health" to the practice of school nursing centers around prevention 
at the primary, secondary, and tertiary levels in the school setting. "Adaptation" is concerned with assessing students" adjustments to internal and external changes in the environment and functioning as a liaison for the student, family, school staff, and health care providers. "Helping relationships" focuses on assisting students build more effective relationships. The concept of "tools" refers to instruments used by school nurses to assess students' health needs. "Systematic process" is a series of methodical steps taken to reach specific results; nursing process is used to assess and meet students' health needs. Standards of school nursing practice were published by the American Nurses Association (ANA) Task Force on Standards of School Nursing Practice in 1983, by the California Commission on Teacher Credentialing (CTC) in 1988 and 1989, and by the American School Health Association (ASHA) in 1989. Although these standards have similarities, some are more comprehensive than others. As in the original research, this replication study will use CTC standards as a structural guide for analysis of the data. The CTC standards were written collaboratively by school nurses, school nurse practitioners, and school nurse educators, with the consultation of a state CTC representative. The CTC standards are grouped into six role concepts. Each one of these role concepts covers certain areas of responsibility for California school 
nursing practice ( See Figure 1 ).

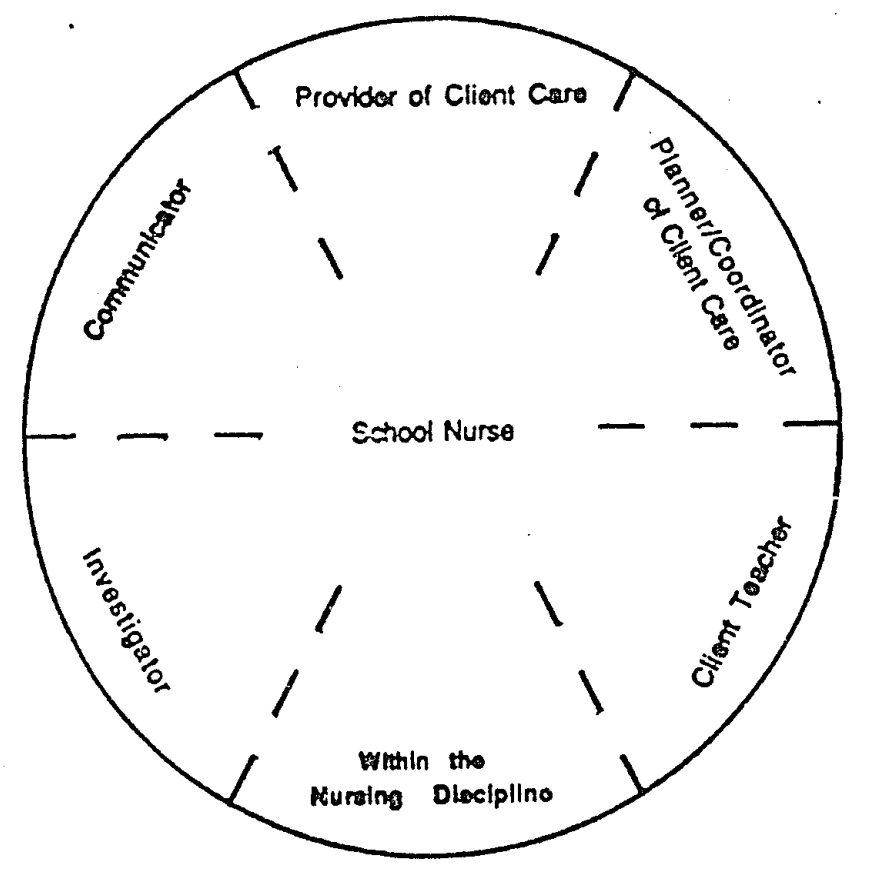

Figure 1. Model of School Nurse Role Concepts

The standards of school nursing practice developed by the ANA served as a basis for these six different role concepts for California school nurses. The California CTC (1989, pp. 27-37) defines the California school nurse role concepts as follows:

1. Provider of Client care. The school nurse applies appropriate theory as a basis for decision making in nursing practice (ANA standard I). The school nurse incorporates the use of the inductive problem-solving process into nursing practice (ANA standard III).

II. Planner and Coordinator of client Care. The school nurse establishes, maintains, and coordinates a 
comprehensive school health program and contributes to the formulation of school.health policy (ANA standard II). The school nurse collaborates with school and other professionals to meet the health, developmental, and educational needs of pupils (ANA standard IV). The school nurse is cognizant of the role of the nurse as a community health professional who utilizes knowledge of community health systems and resources and who functions as a community liaison (ANA standard VII).

III. Client Teacher. The school nurse assists pupils; families, and the school community to achieve optimal. levels of wellness through appropriately designed/delivered health education (ANA standard V).

IV. Within the Discipline of Nursing. The school nurse identifies, delineates, and clarifies the nursing role, promotes the quality assurance in practice, pursues continued professional development, and demonstrates professional conduct (ANA standard VI).

V. Investigator. The school nurse contributes to nursing and school health through innovations in practice and participation in research related activities (ANA Standard VIII).

VI. Communicator. The school nurse uses effective and cogent written, verbal, and non-verbal communication skills, and recognizes the importance of effective communication in school nursing practice. 
Review of the Literature

Over the past decade and a half, a great deal has been written about the role of the school nurse. There is a consensus that the role of the school nurse lacks definition and clarity as a result of its expansion and changing nature. Further research in this area was recommended by the majority of researchers.

Oda (1981) and Regan (1976) recapitulated the history of school nursing over the past 90 years. The latter divided that period into four eras: 1902-1924, 1925-1949, 1950-1969, and 1970-1976. Oda addressed the specific foci, trends, and educational requirements for each epoch. She defined current school nursing as encompassing teaching, counseling, advocacy, coordinating, and care giving roles. Both authors noted the evolving character of the school nurse role. Future roles for nurses providing school health services were proposed.

Feeg (1991), Liebow (1984), Young and Epstein (1991), and Zanga and Oda (1987) commented on the wide range of complex needs and health concerns of today's students. It was pointed out that school nurses are generally well equipped to meet the students' needs and manage their problems. The authors agree that the nurse's presence is essential for the students' wellbeing. Kozlak (1992) goes one step further to assert that school nurse skills are not fully utilized in many instances.. : 
Kozlak (1992) and Oda (1991) emphasized the importance of proving the cost effectiveness of school nursing in this era of drastically reduced funding for school districts. Two different avenues for evaluation of school nurse services were offered. Oda (1981, 1991), Regan (1976), Resnick et al. (1980), Seidenberg (1984), and White (1985) wrote about the extensive misunderstanding of the school nurse role and of the school nurse's contribution to both health and education. According to Oda, this dual role concept, nurse and teacher, is one of the reasons. for the confusion about the school nurse role. Thompson (1989) compared and contrasted American and British school nurses. To her. surprise, she found many similarities: lack of time and resources; misunderstanding of the role; and need for research on the role and function of the school nurse. The image of the school nurse has been likened to a television set with an ineffective antenna, causing a "confusing, cloudy, and restricted picture" (Seidenberg, 1984, p. 363). Strategies fior school nurses to improve their visibility and clarify their images were offered by Resnick et al. (1980) and by Seidenberg (1984). Edwards and Cowell (1985), Oda (1991), Regan (1976), and Ridge (1980) discussed the necessity of education for school nurses at the baccalaureate level or higher. In addition, Oda recommended that school nurses possess skills 
in management, case management, computer literacy, and research.

In 1980, Wold wrote that school nurses have neglected to reign over their own practice area. She urged school nurses to become politically active as a means of taking control over their destiny. Seidenberg (1984) encouraged political involvement for school nurses to increase their understanding of the political process in order to influence health policy and to be active as child advocates.

\section{Related studies}

White (1985) questioned 403 New York state school nurses about the amount of time they yearly spent on 26 school nursing activities and how well they felt they were prepared to perform these activities. The results showed that the nurses spent most of their time on and felt best prepared to perform physical care activities. They felt least prepared for and spent the least time on administrative duties.

Oda (1979) examined the current state of school nursing by having 16 nurses in administrative, supervisory, consultant, and educational positions complete a questionnaire. The findings showed regional variations in staffing levels, school nursing practice, and requirements for school nurse certification. All subjects felt that certification of school nurses would benefit the school nursing profession. 
Santora and steiner (1982) studied school nurses' perceptions of their degree of powerlessness. The researchers surveyed 117 (86 urban and 31 rural) school nurses. They found that the subjects employed in rural and suburban areas perceived their level of powerlessness in their work as low; however, school nurses serving more than one school had significantly higher degrees of powerlessness than did nurses who provided services at a single school. The powerlessness scores were not significantly different for nurses with dissimilar educational preparation, position, or membership in professional organizations. The number of years of experience correlated negatively with the perceived degree of powerlessness.

Lucero (1978) surveyed 88 elementary and secondary teachers and 13 administrators in a San Francisco Bay Area school district to determine which school nurse services were perceived as most valuable. A 34-item questionnaire was used to collect the data. Services ranked highest by the teachers were (in order of importance): vision and hearing screening, reporting screening results to teachers, handling all major accidents, working within the framework of the school law, and handling child abuse cases. The administratórs voted as most important state mandated services (screenings and evaluation and follow-up on student immunization and physical examination status). 
In 1988, Miller and Hopp distributed questionnaires to principals, students, parents, teachers, and school nurses. The 173 participants prioritized school nurse services. Teachers, parents, and students gave highest priority to emergency and first aid services, staff development, and counseling on physical health problems for students. Administrators gave highest priority to screenings, staff development, and counseling of students on health concerns. School nurses, on the other hand, gave highest priority to prevention and control of communicable diseases, classroom and parent health education, and counseling of students on physical and emotional health concerns.

Another study on the perception of the school nurse role was conducted by Nehls (1989). in the San Francisco Bay Area. Two hundred and forty-nine students, parents, and teachers at the secondary level ranked the significance of services expected of the school nurse on a 39-item likert scale designed by the researcher. All three groups of respondents queried rated handling emergencies as the most important service to be provided by the school nurse. students and parents rated development of first aid policies and procedures as second most important, whereas teachers ranked listing of students with major health problems the second most important service. The service ranked as third most important by students was maintaining student health 
files, by parents was prevention of communicable diseases, and by teachers was establishing first aid policies and procedures.

Sadik (1992) examined teachers' perceptions of the school nurse role. One hundred and seventy-eight elementary and middle school teachers responded to the 44 -item questionnaire developed by Nehls and modified by Palmer and Young. The teachers designated the following as the most important school nurse services: providing vision and hearing screening, emergency care, and identification of child abuse shared highest ranking; follow-up on student health concerns for teachers and serving as a liaison between the student, family, the physician, and the teachers shared second highest ranking.

Cassel (1993) conducted a study on parents' perceptions of the school nurse role. She utilized the Palmer and Young modified version of Nehls' School Nurse Data Collection Tool for her research. One hundred and thirty four questionnaires were completed and returned by parent members of the California Parent Teachers Association (PTA). The parents rated the provision of emergency care as the most important school nurse service. Identification and referral of child abuse was rated second most important service. The subjects rated hearing and vision screening third most important, establishing and maintaining first aid policies and procedures fourth, management of health 
hazards on campus fifth, and containment of communicable diseases sixth most important school nurse service. School nurses' perceptions of the value of their services were investigated by Palmer (1993). Palmer and Young adapted Nehls' survey instrument for this study. Three hundred school nurses attending the 41 st Annual California School Nurses Organization (CSNO) conference in 1991 participated in the study. Ninety-five percent of all subjects rated acting as a liaison between the student, the family, the doctor, and the teacher as the most important school nurse service. The school nurses rated providing individual student health counseling as the second most important service. Other services rated very important were (in declining order of importance): maintaining a student health problems list, investigating and reporting back on student health concerns referred by classroom teachers, identifying and referring child abuse, carrying on an active program for the prevention of communicable diseases, and providing hearing and vision screening.

\section{Summary}

From the literature review, it is evident that the role of the school nurse has unfurled, expanded, and become more elusive since its inception. The role encompasses many subroles and varies depending on the expectations of teachers, students, parents, administrators, and school 
nurses.

Services viewed as most important by the majority of teachers in the above cited studies were: vision and hearing screening, management of emergencies/first aid, identification of child abuse cases, and investigation of student health problems. All of these services fall under the category of CTC Role Concept I, Provider of Client Care. Two of the services are also components of CTC Role Concept II, Planner and Coordinator of Client Care. Currently, several other studies on this subject are being planned at San Jose State University. Once the results of these and other future studies are known, the information generated by all studies can be analyzed. This analysis will facilitate clarification of the school nurse role. 


\section{Chapter 3}

\section{RESEARCH DESIGN AND METHODOLOGY}

Research Design

The purpose of this study was to determine which components of the school nurse role are perceived as most important by elementary and junior high school teachers. A non-experimental descriptive survey design was used for this partial replication study of research conducted in a San Francisco Bay Area school district by Sadik in 1992. According to Burns and Grove (1987, p. 243), this type of design may be used for the purpose of identifying problems with current practice or justifying current practice. The research question for this study was: What services do elementary and junior high school teachers view as most important for the school nurse to provide? Setting and Sample

The convenience sample selected for participation. in this study included all elementary and junior high school teachers of a large San Francisco Bay Area school district. This urban/suburban district has 20,528 elementary and junior high school students. The total number of students in this particular district is 28,000 . The population is diverse in terms of socioeconomic, ethnic, and religious backgrounds. 'It includes many minority and non-English speaking students. 
Human Subjects Approval.

A proposal for this study was presented to the San Jose State University Human Subjects Institutional Review Board. The request for exemption from Human Subjects Review was granted since participation in the study did not pose any risks to the subjects (see Appendix D). Data Collection Tool

The questionnaire used in this study, the School Nurse Service (SNS) Data Collection Tool (see Appendix B), was designed by Nehls in 1989 and modified by Palmer and Young in 1991. This. instrument was pilot tested and evaluated for clarity, content validity, and completeness by 9 school nurse experts, but not for reliability. Written permission to use the tool was obtained (see Appendix C).

The tool consists of 44 items listing school nurse services to be ranked by the teachers from very important to not important on a 4-point Likert scale. Examples of the types of items on the questionnaire include providing emergency care to students, health counseling to staff, teaching in classroom, and participating in budget planning. A Likert value of 4 was assigned to a "very important" · response, a value of 3 was assigned to "important," a value of 2 was assigned to "somewhat important," and a value of 1 was assigned to "not important." Question 45 asked the subjects to list any other services omitted but considered important. Finally, there is a brief section 
for demographic information. Subjects are asked about their age, gender, grade level of students taught, type of students (general, special, or other education), and number of years of experience as an educator.

Data Collection Procedures

Permission to conduct the study and to enlist the assistance of the school nurses in the gathering of the data was received from the district Coordinator of Pupil Services (see Appendix E). All nurses in the district readily agreed to help with the distribution and retrieval of the questionnaires. The total number of full time school nurse positions in the district is 8. All elementary and junior high schools have a school nurse on site one day per week.

The researcher provided the school nurses with the research packets consisting of a cover/consent letter (see Appendix A), a questionnaire, and an envelope at one of their monthly meetings. The school nurses distributed the packets to the teachers in each of their elementary and junior high schools; a total of 970 questionnaires was distributed. There was a request in the cover/consent letter that teachers return the distributed questionnaires in the provided envelope to the nurses' mailboxes within 5 days. The nurses then returned the questionnaires to the district secretary where they were later collected by the researcher. The researcher was not employed by 
or otherwise known to the participating school district. A total of 242 questionnaires were returned by teachers. Analysis Procedures

A descriptive statistical analysis was utilized to analyze the data. Frequencies, percentages, and mean values were determined. School nurse services were categorized according to California Commission on Teacher Credentialing (CTC) Role Concepts. The school nurse role concepts are defined by the CTC as Provider of Client Care, Planner and Coordinator of Client Care, Client Teacher, Within the Discipline of Nursing, Investigator, and Communicator. 


\section{Chapter 4}

\section{ANALYSIS AND INTERPRETATION OF THE DATA}

Introduction

The purpose of this chapter is to present the study findings. A description of the sample is followed by results of the study. The objective of this study was to identify which services elementary and junior high school teachers consider most important for the school nurse to provide. The revised School Nurse Services Data Collection Tool by Nehls was used to gather data from teachers. The data were analyzed to determine descriptive statistics including frequencies, percentages, and means. The data are presented in the following order: (a) characteristics of the sample, (b) frequency and percentage of survey items, (c) role concept, mean, and rank of the items, and (d) report of responses to the open-ended question. Characteristics of the Sample

The sample for this study consisted of all elementary and junior high school teachers of a San Francisco Bay Area school district. School nurses distributed a total of 970 questionnaires to teachers at their school sites. Two hundred and forty-two teachers returned a completed questionnaire; a return rate of $25 \%$. The researcher was not associated with the district. Table 1 depicts the demographic characteristics of the participants. 
Table 1

Demographic Characteristics of the Sample $(N=242)$

Characteristic and Group $\underline{n}$ क

Age in Years

$20-29$

$30-39$

$40-49$

50 plus

Unknown

Gendex

$$
\begin{aligned}
& \text { Female } \\
& \text { Male }
\end{aligned}
$$$$
\text { Unknown }
$$

Type of students

$$
\begin{aligned}
& \text { Regular } \\
& \text { Special } \\
& \text { Other }
\end{aligned}
$$

Unknown

Grade Levels Taught

$$
\begin{aligned}
& \text { Prek-2 ( } 1 \text { grade level) } \\
& 3-6(1 \text { grade level }) \\
& \text { PreK-6 (2-7 grades levels }) \\
& 7 \text { or } 8 \\
& 7 \text { and } 8 \\
& \text { Unknown }
\end{aligned}
$$

Years of Teaching Experience

$$
\begin{aligned}
& 1-4 \\
& 5-9 \\
& 10-14 \\
& 15-19 \\
& 20 \text { plus } \\
& \text { Unknown }
\end{aligned}
$$

Years Employed by District

$$
\begin{aligned}
& 1-4 \\
& 5-9 \\
& 10-14 \\
& 15-19 \\
& 20 \text { plus } \\
& \text { Unknown }
\end{aligned}
$$

$\begin{array}{lr}18 & 7 \\ 38 & 16 \\ 95 & 39 \\ 80 & 33 \\ 11 & 5\end{array}$

191

39

12

79

16

5

$113 \quad 47$

$42 \quad 17$

$25 \quad 10$

$62 \quad 26$

$59 \quad 24$

$70 \quad 29$

$51 \quad 21$

$13 \quad 6$

$32 \quad 13$

17.7

$28 \quad 12$

$40 \quad 16$

$31 \quad 13$

$27 \quad 11$

$108 \quad 45$

$8 \quad 3$

$\begin{array}{rr}23 & 9 \\ 33 & 14 \\ 16 & 7 \\ 8 & 3 \\ 41 & 17 \\ 121 & 50\end{array}$


The majority of the teachers were age forty or older (72\%) and were female (79\%). Forty-five percent had over 20 years of teaching experience; 128 had 1-4 years. Close to half $(47 \%)$ of the teachers were involved with regular students. Seventeen percent worked with students in special education, $10 \%$ in other types of education, and $26 \%$ did not specify their specialty. Most teachers (74\%) worked with elementary students, 198 with junior high students, and $7 \%$ did not respond to this question. Fifty-nine percent taught one grade level, while $34 \%$ taught from two to seven different grade levels. Only $50 \%$ of the participants responded to the question asking the number of years employed by the district. The largest group of those teachers who answered this question (34\%) had taught in the district for more than 20 years. The minority $(7 \%)$ of those teachers who answered this question had been with the district for 15-19 years. Nine percent of those teachers who answered this question had been employed by the district for 1-4 years.

Frequency and Mean of Responses

Data from the sample were analyzed to determine the frequency and mean of the participants' responses. The teachers were asked to rank the importance of various school nurse services (44 items) on a 4 -point Likert scale. A Likert value of 4 was assigned to "very important (very Impt)" responses; a value of 3 was assigned to "important 
(Impt)" responses; a value of 2 was assigned to "somewhat important (somewhat Impt)" responses; and a value of 1 was assigned to "not important (not Impt)" responses. Frequency and percentages for all services are presented in Table 2.

Responses to the questionnaires were rank ordered according to the level of importance attributed to the items by participants. A numerical mean (M) to two decimal points was calculated for each service. The highest mean value assigned to an individual school nurse service was 3.85 , the lowest was 1.15 . Services receiving a mean (M) value of 3.50 or higher were designated as "very important," those with $\underline{M}=3.00-3.49$ "important," those with $\underline{M}=2$.00-2.99 "somewhat important," and those with $\underline{M}=$ less than 2.00 "not important."

School nurse services were categorized according to the California Commission on Teacher Credentialing (CTC) Role Concepts to facilitate analysis of the data. All services listed in the School Nurse Services (SNS) Data Collection Tool (except item 19) are components of one or more of the six school nurse role concepts. These role concepts are defined by the California CTC as (I) provider of client care, (II) planner and coordinator of client care, (III) client teacher, (IV) within the discipline of nursing, (V) investigator, and (VI) communicator. None of the items included in SNS Tool fits the role of 
investigator. Table 3 presents the role concept for school nurse services and the mean (M) value and rank of responses. School nurse services rated very important by teachers included: Item 2, hearing and vision screening; Item 33 , maintain and share a list of student health problems with teachers; Item 5, provide emergency care; Item 3, function as student health liaison with family, physician, and teacher; and Item 35, investigate student health concerns for teachers. These items were all classified under either the role of care giver or planner/coordinator of care, or both. In addition, two of these "very important" services fitted the role of communicator.

Twelve items were rated important. Nine of these corresponded with the role of planner/coordinator and three related to the role of care giver as well. The remaining services related to the teacher or communicator role.

Analysis of the responses indicated that participating teachers regarded the majority of the listed school nurse services (23) somewhat important. The services rated as such represented role concepts I-III somewhat equally (7-9 times) and role concepts IV and VI once each. Four services were considered not important at all. Of these services, items 8 and 22--community activities and coordinate lunch program--fit role concept II. Item 9, staff health counseling, fits role concepts I, III, and VI. Item 19, record attendance, did not fit any role concept. 
Table 2

Freguency and Percentage of Response to Items $1-44 \quad(N=242)$

\begin{tabular}{|c|c|c|c|c|c|}
\hline \multicolumn{2}{|l|}{ Item } & \multirow{2}{*}{$\begin{array}{r}\text { Very } \\
\text { Impt } \\
\\
f \\
8\end{array}$} & \multirow{2}{*}{$\begin{array}{r}\text { Impt } \\
\\
\text { f } \\
q\end{array}$} & \multirow{2}{*}{$\begin{array}{r}\text { Some- } \\
\text { what } \\
\text { Impt } \\
\text { f } \\
8\end{array}$} & \multirow{2}{*}{$\begin{array}{r}\text { Not } \\
\text { Impt } \\
\text { f } \\
8\end{array}$} \\
\hline & & & & & \\
\hline 1 & Classroom teaching & $\begin{array}{l}65 \\
27\end{array}$ & $\begin{array}{l}79 \\
33\end{array}$ & $\begin{array}{l}65 \\
27\end{array}$ & $\begin{array}{l}30 \\
13\end{array}$ \\
\hline 2. & Hearing/vision screening & $\begin{array}{r}209 \\
87\end{array}$ & $\begin{array}{l}28 \\
12\end{array}$ & $\begin{array}{l}0 \\
0\end{array}$ & $\begin{array}{l}3 \\
1\end{array}$ \\
\hline 3. & Health liaison student & $\begin{array}{r}180 \\
75\end{array}$ & $\begin{array}{l}39 \\
16\end{array}$ & $\begin{array}{r}18 \\
7\end{array}$ & $\begin{array}{l}4 \\
2\end{array}$ \\
\hline 4. & Health hazards at school & $\begin{array}{r}133 \\
55\end{array}$ & $\begin{array}{l}74 \\
31\end{array}$ & $\begin{array}{l}30 \\
12\end{array}$ & $\begin{array}{l}5 \\
2\end{array}$ \\
\hline 5 . & Emergency care to students & $\begin{array}{r}188 \\
80\end{array}$ & $\begin{array}{l}27 \\
11\end{array}$ & $\begin{array}{r}16 \\
7\end{array}$ & $\begin{array}{l}5 \\
2\end{array}$ \\
\hline 6. & $\begin{array}{l}\text { Contain communicable } \\
\text { diseases }\end{array}$ & $\begin{array}{r}102 \\
43\end{array}$ & $\begin{array}{l}88 \\
37\end{array}$ & $\begin{array}{l}44 \\
19\end{array}$ & $\begin{array}{l}1 \\
1\end{array}$ \\
\hline 7.1 & $\begin{array}{l}\text { Health counseling to } \\
\text { students }\end{array}$ & $\begin{array}{r}102 \\
43\end{array}$ & $\begin{array}{l}88 \\
36\end{array}$ & $\begin{array}{l}40 \\
17\end{array}$ & $\begin{array}{l}9 \\
4\end{array}$ \\
\hline 8. & $\begin{array}{l}\text { Health related community } \\
\text { activities }\end{array}$ & $\begin{array}{r}18 \\
7\end{array}$ & $\begin{array}{l}37 \\
15\end{array}$ & $\begin{array}{l}98 \\
41\end{array}$ & $\begin{array}{l}88 \\
37\end{array}$ \\
\hline 9. & Health counseling for staff & $\begin{array}{r}13 \\
5\end{array}$ & $\begin{array}{l}23 \\
10\end{array}$ & $\begin{array}{l}60 \\
25\end{array}$ & $\begin{array}{r}143 \\
60\end{array}$ \\
\hline 10 & $\begin{array}{l}\text { CPR instruction to staff and } \\
\text { students }\end{array}$ & $\begin{array}{l}60 \\
25\end{array}$ & $\begin{array}{l}61 \\
26\end{array}$ & $\begin{array}{l}81 \\
34\end{array}$ & $\begin{array}{l}36 \\
15\end{array}$ \\
\hline 11 & $\begin{array}{l}\text { Committee to assess } \\
\text { academic difficulties }\end{array}$ & $\begin{array}{l}49 \\
20\end{array}$ & $\begin{array}{l}80 \\
33\end{array}$ & $\begin{array}{l}78 \\
33\end{array}$ & $\begin{array}{l}33 \\
14\end{array}$ \\
\hline 12 . & $\begin{array}{l}\text { Coordinate sevices to } \\
\text { handicapped students }\end{array}$ & $\begin{array}{l}24 \\
10\end{array}$ & $\begin{array}{l}60 \\
26\end{array}$ & $\begin{array}{l}92 \\
40\end{array}$ & $\begin{array}{l}57 \\
24\end{array}$ \\
\hline 13 & $\begin{array}{l}\text { Classroom alcohol/drug } \\
\text { education }\end{array}$ & $\begin{array}{l}26 \\
11\end{array}$ & $\begin{array}{l}48 \\
21\end{array}$ & $\begin{array}{r}111 \\
47\end{array}$ & $\begin{array}{l}49 \\
21\end{array}$ \\
\hline
\end{tabular}




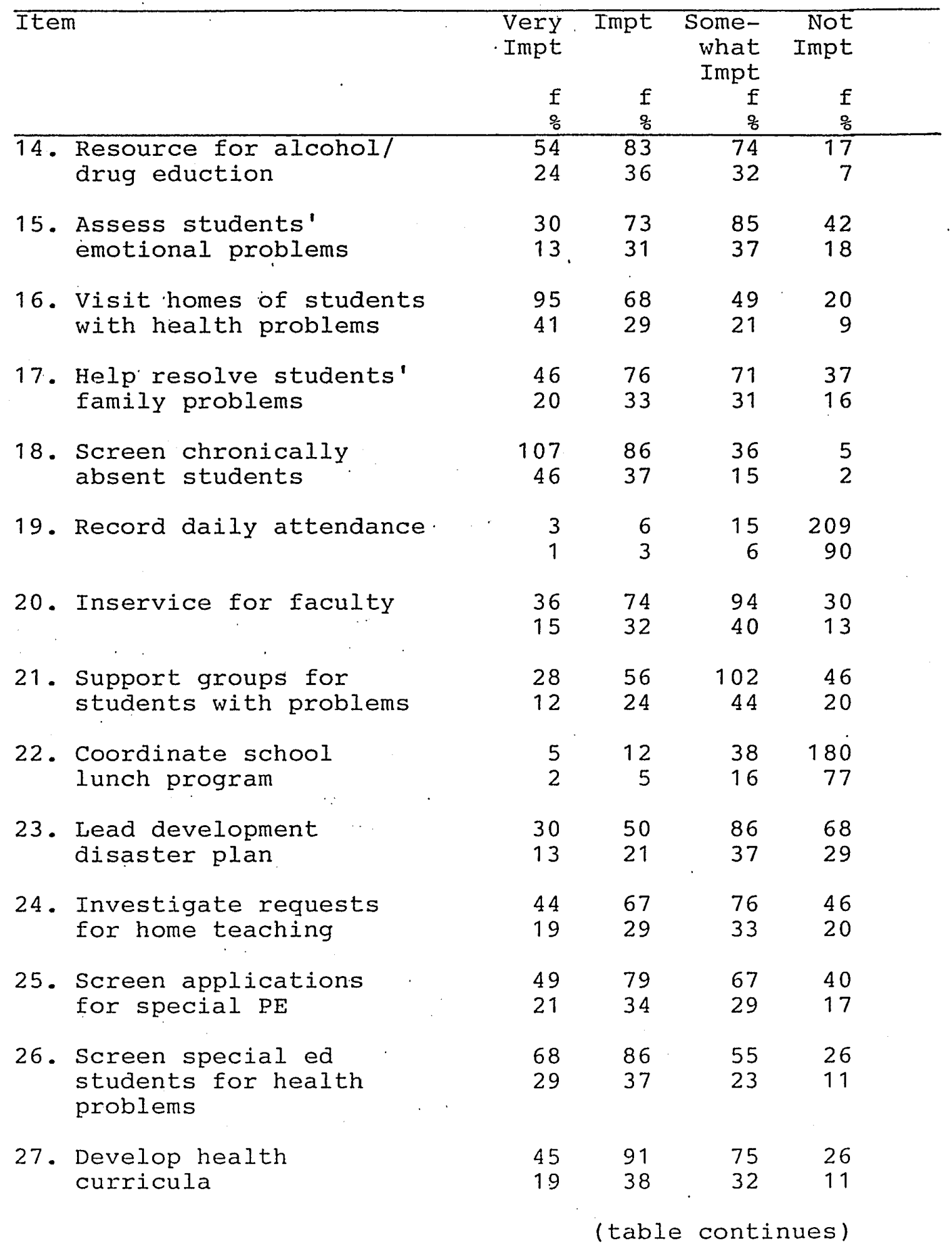




\begin{tabular}{|c|c|c|c|c|}
\hline Item & $\begin{array}{l}\text { Very } \\
\text { Impt }\end{array}$ & Impt & $\begin{array}{r}\text { Some- } \\
\text { what } \\
\text { Impt } \\
\text { f } \\
\text { o }\end{array}$ & $\begin{array}{l}\text { Not } \\
\text { Impt }\end{array}$ \\
\hline 28. Inservice to parents & $\begin{array}{l}30 \\
13\end{array}$ & $\begin{array}{l}77 \\
32\end{array}$ & $\begin{array}{l}96 \\
40\end{array}$ & $\begin{array}{l}35 \\
15\end{array}$ \\
\hline $\begin{array}{l}\text { 29. Keep current student } \\
\text { immunization status }\end{array}$ & $\begin{array}{r}138 \\
58\end{array}$ & $\begin{array}{l}57 \\
24\end{array}$ & $\begin{array}{l}26 \\
11\end{array}$ & $\begin{array}{r}18 \\
8\end{array}$ \\
\hline $\begin{array}{l}\text { 30. Identify and refer drug- } \\
\text { abusing students }\end{array}$ & $\begin{array}{r}107 \\
45\end{array}$ & $\begin{array}{l}96 \\
40\end{array}$ & $\begin{array}{l}27 \\
11\end{array}$ & $\begin{array}{l}8 \\
3\end{array}$ \\
\hline $\begin{array}{l}\text { 31. Maintain first aid } \\
\text { policies for school }\end{array}$ & $\begin{array}{r}121 \\
51\end{array}$ & $\begin{array}{l}83 \\
35\end{array}$ & $\begin{array}{l}32 \\
13\end{array}$ & $\begin{array}{l}3 \\
1\end{array}$ \\
\hline $\begin{array}{l}\text { 32. Provide inservice to } \\
\text { staff on basic first aid }\end{array}$ & $\begin{array}{r}108 \\
46\end{array}$ & $\begin{array}{l}75 \\
32\end{array}$ & $\begin{array}{l}40 \\
17\end{array}$ & $\begin{array}{r}14 \\
6\end{array}$ \\
\hline $\begin{array}{l}\text { 33. Keep and share student } \\
\text { health problem list } \\
\text { with teachers }\end{array}$ & $\begin{array}{r}183 \\
77\end{array}$ & $\begin{array}{l}44 \\
18\end{array}$ & $\begin{array}{l}8 \\
3\end{array}$ & $\begin{array}{l}4 \\
2\end{array}$ \\
\hline $\begin{array}{l}\text { 34. Identify and refer } \\
\text { students who are victims } \\
\text { of abuse }\end{array}$ & $\begin{array}{r}139 \\
58\end{array}$ & $\begin{array}{l}75 \\
31\end{array}$ & $\begin{array}{r}18 \\
8\end{array}$ & $\begin{array}{l}7 \\
3\end{array}$ \\
\hline $\begin{array}{l}\text { 35. Investigate health } \\
\text { concerns for teachers }\end{array}$ & $\begin{array}{r}167 \\
70\end{array}$ & $\begin{array}{l}61 \\
26\end{array}$ & $\begin{array}{l}9 \\
4\end{array}$ & $\begin{array}{l}2 \\
0\end{array}$ \\
\hline $\begin{array}{l}\text { 36. Maintain accurate health } \\
\text { files on students }\end{array}$ & $\begin{array}{r}143 \\
59\end{array}$ & $\begin{array}{l}68 \\
28\end{array}$ & $\begin{array}{r}20 \\
8\end{array}$ & $\begin{array}{r}10 \\
4\end{array}$ \\
\hline $\begin{array}{l}\text { 37. Provide immunizations } \\
\text { for students }\end{array}$ & $\begin{array}{l}32 \\
14\end{array}$ & $\begin{array}{l}47 \\
21\end{array}$ & $\begin{array}{l}56 \\
24\end{array}$ & $\begin{array}{l}94 \\
41\end{array}$ \\
\hline $\begin{array}{l}\text { 38. Provide routine } T B \\
\text { testing to staff }\end{array}$ & $\begin{array}{l}53 \\
23\end{array}$ & $\begin{array}{l}45 \\
19\end{array}$ & $\begin{array}{l}57 \\
24\end{array}$ & $\begin{array}{l}80 \\
34\end{array}$ \\
\hline $\begin{array}{l}\text { 39. Provide special } \\
\text { procedures to students }\end{array}$ & $\begin{array}{l}65 \\
29\end{array}$ & $\begin{array}{l}45 \\
20\end{array}$ & $\begin{array}{l}55 \\
24\end{array}$ & $\begin{array}{l}83 \\
28\end{array}$ \\
\hline $\begin{array}{l}\text { 40. Monitor administration } \\
\text { of medications }\end{array}$ & $\begin{array}{l}65 \\
27\end{array}$ & $\begin{array}{l}69 \\
29\end{array}$ & $\begin{array}{l}65 \\
27\end{array}$ & $\begin{array}{l}41 \\
17\end{array}$ \\
\hline $\begin{array}{l}\text { 41. Plan budget for the } \\
\text { health program }\end{array}$ & $\begin{array}{l}59 \\
25\end{array}$ & $\begin{array}{l}88 \\
37\end{array}$ & $\begin{array}{l}56 \\
24\end{array}$ & $\begin{array}{l}33 \\
14\end{array}$ \\
\hline
\end{tabular}




\begin{tabular}{lrrrr}
\hline Item & $\begin{array}{r}\text { Very } \\
\text { Impt }\end{array}$ & Impt & $\begin{array}{r}\text { Some- } \\
\text { what }\end{array}$ \\
& & & $\begin{array}{r}\text { Not } \\
\text { Impt }\end{array}$ \\
& 8 & 8 & $f$ & $f$ \\
\hline 42. Document, evaluate, and & 50 & 68 & 86 & 30 \\
report services & 21 & 29 & 37 & 13 \\
43. Present program to & 49 & 89 & 69 & 29 \\
school board & 21 & 38 & 29 & 12 \\
44. Evaluate own practice & 83 & 101 & 44 & 5 \\
& 36 & 43 & 19 & 2
\end{tabular}

Table 3

Items 1-44 Rank Ordered by Mean (M) Score $(N=242)$ and Classified According to California CTC Role Concepts (RC)

RC I: Provider of Care, RC II: Planner/Coordinator of Care, RC III: Teacher, IV: Within the Discipline of Nursing, RC V: Investigator, and VI: Communicator Item

Role

\begin{tabular}{lllll} 
\# Content & Concept & M & Rank \\
\hline 2. Hearing/Vision & I & 3.85 & 1st \\
33. Health Problems List & II, VI & 3.70 & 2nd \\
5. Emergency Care & I & 3.69 & 3 rd \\
3. Health Liaison & II, VI & 3.64 & 4 th \\
35. Health Concerns & I, II & 3.64 & 4 th \\
34. Child Abuse & I, II & 3.45 & 6 th \\
36. Health Files & II . & 3.43 & 7 th \\
& & & & (table continues)
\end{tabular}




\begin{tabular}{|c|c|c|c|c|}
\hline \multirow{2}{*}{$\begin{array}{l}\text { Item } \\
\# \\
\end{array}$} & & \multicolumn{3}{|l|}{ Role } \\
\hline & & Concept & $M$ & Rank \\
\hline 4. & Health Hazards & $I I$ & 3.38 & 8 th \\
\hline 31. & First Aid Policies & II & 3.35 & 9 th \\
\hline 29 . & Assess Immunizations & II & 3.32 & $10 \mathrm{th}$ \\
\hline 30 & Identify Drug Abuse & $I, I I$ & 3.27 & 11 th \\
\hline 18. & Screen Chron. Absentees & $I, I I$ & 3.26 & $12 t h$ \\
\hline 6 . & Communicable Diseases & II & 3.24 & $13 t h$ \\
\hline 7 . & Health Counsel. Students & $I$ & 3.18 & 14 th \\
\hline 32 . & Teach staff First Aid & III & 3.17 & 15 th \\
\hline 44. & Evaluate Own Practice & VI & 3.12 & 16 th \\
\hline 16. & Make Home Visit & II & 3.03 & 17 th \\
\hline 26 . & Special Education & $I, I I$ & 2.83 & 18 th \\
\hline 14. & Resource Drug Education & III & 2.76 & 19 th \\
\hline 1. & Classroom Education & III & 2.75 & $20 t h$ \\
\hline 41. & Budget Planning & II & 2.73 & $21 s t$ \\
\hline 43. & School Board Presentation. & VI & 2.67 & $22 \mathrm{nd}$ \\
\hline 40 & Monitor Medications & $I, I I$ & 2.66 & $23 \mathrm{rd}$ \\
\hline 27. & Devel. Health Curricula & III & 2.65 & 24 th \\
\hline 10 & CPR Instruction & $\operatorname{III}$ & 2.61 & 25 th \\
\hline 11. & School Committee & I & 2.60 & 26 th \\
\hline 42 . & Document Services & IV & 2.59 & 27 th \\
\hline $25^{\circ}$ & Screen Special. $\mathrm{PE}$ & II & 2.58 & $28 t h$ \\
\hline 17. & Assess Family Problems & I & 2.56 & 29 th \\
\hline
\end{tabular}




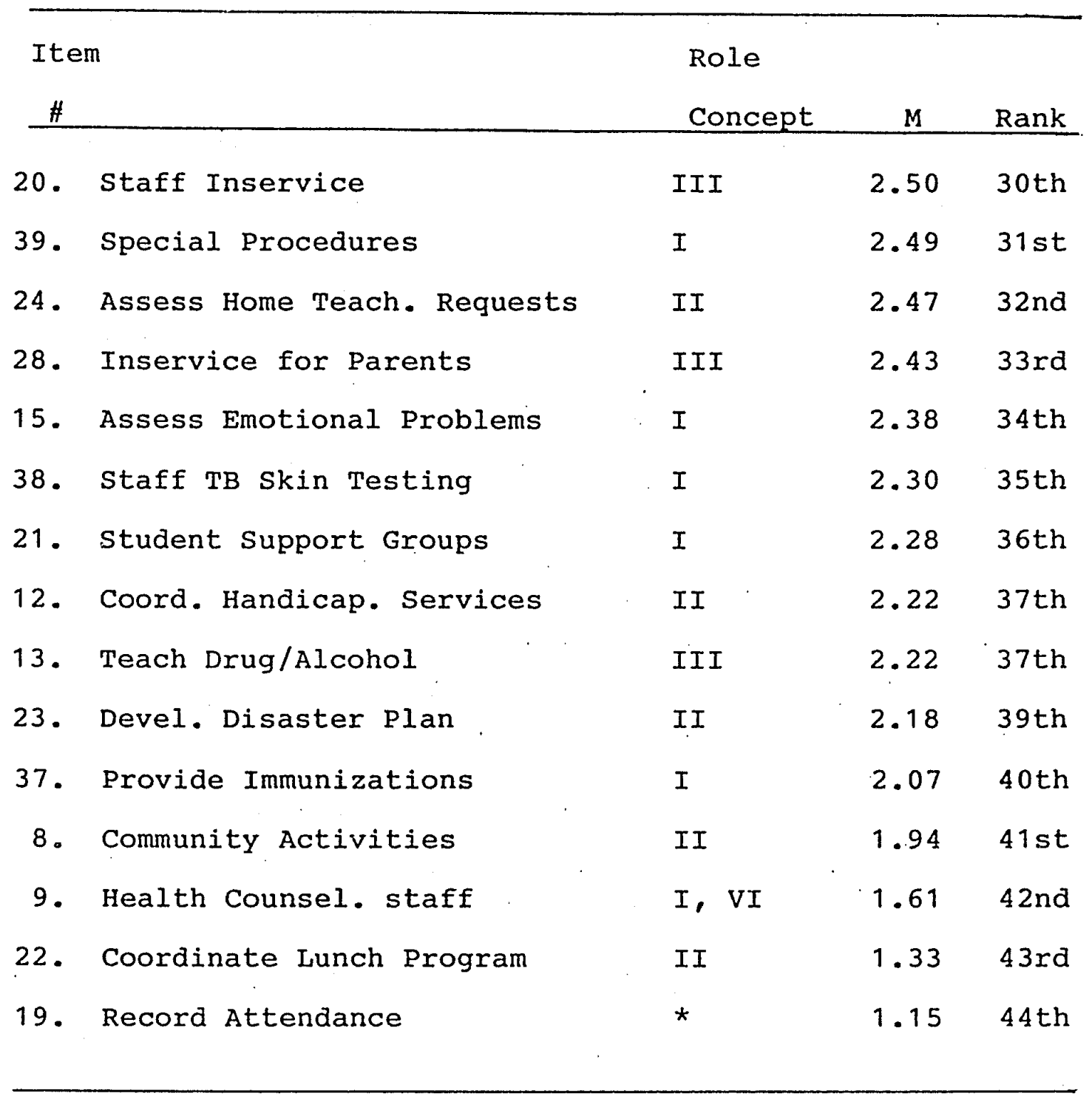

Note: * indicates item not appropriate for CTC role concepts. In this survey's top 5 services the roles of care provider and planner/coordinator were equally important. The role of care provider was the most important role when looking at Sadik's (1992) 5 top services. In both studies the role of communicator had the highest overall mean, the role of care provider the 2nd highest mean, and the 
role of planner/coordinator the $3 x d$ highest mean. The roles of teacher and within the profession ranked 4 th and 5 th, respectively, in this study, whereas the reverse was found in Sadik's (1992) study. See Table 4 for comparison of means.

Table 4

Comparison of Means of Role Concepts Representing 5 Most. Important Services

\begin{tabular}{lcr}
\hline $\begin{array}{l}\text { Role } \\
\text { Concept }\end{array}$ & $\begin{array}{c}\text { Average } \\
\text { Mean } \\
\text { Kremer }\end{array}$ & $\begin{array}{c}\text { Average } \\
\text { Mean } \\
\text { Sadik }\end{array}$ \\
\hline I Care Provider & 3.58 & 3.82 \\
II Planner/Coordinator & 3.58 & 3.76 \\
\hline
\end{tabular}

Comparison Overall Average Mean of Role Concepts

\begin{tabular}{lcc} 
Role & $\begin{array}{c}\text { Average } \\
\text { Mean } \\
\text { Kremer }\end{array}$ & $\begin{array}{c}\text { Average } \\
\text { Mean } \\
\text { Sadik }\end{array}$ \\
\hline VI Communicator & 3.28 & 3.40 \\
I Care Provider & 3.07 & 3.29 \\
II Planner/Coordinator of Care & 3.02 & 3.27 \\
III Teacher & 2.64 & 2.75 \\
IV Within Profession & 2.59 & 2.80 \\
V Researcher & N/A* & \\
\end{tabular}

Note: ${ }^{\star} / \mathrm{A}$ denotes not applicable. None of the services

listed represented the role of researcher.

Responses to the Open-Ended Question

In question 45 teachers were invited to list services omitted in the SNS Tool but deemed important. Fifty-nine (258) of the participants responded to this invitation. The majority of the teachers who responded to this question repeated items already included in the SNS Data Collection Tool. Examples of such.comments, were an anti-smoking 
campaign which is covered under item \#13," classroom alcohol and drug education," taking care of injured which is covered under item \#5," emergency care," and participate in student study Team (SST) meetings which is covered under item \#11, "be member of committee to assess academic difficulties." Additional recommended services fitting the role of care provider were obtaining Health and Developmental Histories from parents when needed, assessing students for asthma and allergies, providing scoliosis screening to elementary students, and performing dental inspections. Additional recommended services fitting the role of planner/coordinator of care were checking records of immigrant students for Tuberculosis and referring students in need of eye-glasses or hearing aids to Lions Club, California Children's Services (CCS), or other community agencies. Additional recommended services fitting the role of teacher were informing staff on Acquired Immunodeficiency Syndrome (AIDS) and Human Immunodeficiency Virus (HIV) including implementing universal precautions, supervising staff health practices regarding blood borne pathogens, and presenting information on scoliosis screening to parents and teachers at the elementary level. Additional recommended services fitting the role of communicator were making a list of local counselors available to parents, providing information on scoliosis screening to elementary teachers and parents, and referring students in need of 
eye-glasses and hearing alds to the Lions Club, CCS, or other community agencies.

More often than not teachers offered comments rather than proposing additional services for the SNS Tool. A frequently made remark was that, due to 1 imited time avallable to their school nurse, items considered very important or important were rated somewhat or not important. Several teachers $(\underline{n}=6)$ stated that "too much time is spent on paper work and not enough on real nursing." It was suggested that clerical stafi take over this responsibility to free school nurse time for nursing duties. Other suggestions. Included increasing funding for school nurse services, increasing the district's awareness of the significance of school nurse services, having aides perform the "somewhat important" services, and eliminating school nurses as no funding is available for their services $(\underline{n}=1)$.

A number of teachers expressed their appreciation for their school nurse. Typical remarks were: "Our school nurse does a fantastic job in the limited time available"; "She is wonderful, we cannot afford to do without her"; "Heaven help us if they cut our nurses out of the budget." Not surprisingly, the request for increased school nurse time was made by 258 of the respondents. One teacher commented: "I am disgusted that school nurses are assigned only $\frac{1}{2}-1$ day per week to each school." Another remarked: "allowing. secretaries to do school nurses" jobs is unsafe." 
Summary

The purpose of this study was to identify school nurse services considered most important by teachers. In this chapter the characteristics of the sample were discussed. The findings of this study which were obtained by using the SNS Data Collection Tool were shown in Tables 2 and 3. Responses to. the open ended question were explored. In the following chapter, the study and its results are summarized. Conclusions and limitations are discussed. Finally, recommendations for further research and school nursing practice are offered. 
Chapter 5

CONCLUSIONS AND RECOMMENDATIONS

Summary of study

Chapter 5 contains a summary and discussion of the study, its findings, and limitations. It includes recommendations for future research and for practice. This study was a partial replication of research conducted by Sadik in 1992. The research question for the study was: What services do elementary and junior high school teachers view as most important for the school nurse to provide? Information was gathered from 242 teachers by using the 1991 Palmer and Young modified version of The School Nurse Service Data Collection Tool (Nehls, 1989). School nurse services were categorized. according to the California CTC Role Concepts. Responses were analyzed and rank ordered according to importance based on the mean $(\underline{M})$. The services perceived by the teachers as most important were hearing and vision screening, student health problems list, emergency care, health liaison, and health concerns. These services were classified under CTC Role Concepts I, II, and VI; the role of care provider, care planner and coordinator, and communicator, respectively.

Conclusions

The results of this study suggest that teachers regard school nurse services as important. Participants rated 
$39 \%$ of the listed services as very important or important and $52 \%$ as somewhat important. Nine percent of the services were considered not important. The services viewed as most important $(\underline{M}=3.5-4.0)$ related to the role of care provider, planner/coordinator, and communicator. These findings indicate that teachers highly value direct care for their students and being informed regarding their students' health status.

The five services ranked highest were: hearing and vision screening; sharing student health problems with teachers; providing emergency care; liaison with student, family, physician, and teacher; and, investigating health concerns for teachers. The results of this partial replication of Sadik's (1992) study correspond closely with her findings. Seven services listed among the ten most important in both studies were hearing and vision, emergency care, health concerns, liaison, health problems list, health files, and health hazards. The findings of this study also resemble the results of Nehls' (1989) survey.

This study and Nehls' study listed among their ten most important services emergency care, health problems list, first aid policies, hearing and vision, liaison, health concerns, health files, and immunization audits. Lucero's (1978) findings were similar. Vision and hearing screening, handling accidents, and child abuse were considered most important by her teachers. 
Cassel's (1993) findings corresponded with this study's results as well. The parents in her study considered $80 \%$ of this study's top ten services most important.

Palmer's (1993) results were close to the findings of this study with one exception; the school nurses in her study ranked emergency care-21st. In this study it ranked 3rd. Perhaps school nurses do not view this service as one of their priorities because they, more often than not, are unavailable to provide this service. In many schools staff have been trained to provide first aid at the school site and perform this service effectively.

Twelve services were rated important $(\underline{M}=3.0-3.49)$. The majority of these services related to the role of planner and coordinator of care, four related to the role of care provider, and one to the role of teacher. Some of the services corresponded with more than one role because role concepts overlap one another. Teaching staff first aid was the only service pertaining to teaching considered important in this study.

The largest number of services (23) ranked somewhat important $(\underline{M}=2.0-2.99)$. This finding may partially be explained by the fact that a number of teachers mentioned in the open-ended question answer section to have rated "somewhat important" services they considered "important," stating that they know the school nurse would lack time to provide all services deemed important. Of these somewhat 
important services, eight corresponded with the role of care provider, seven with the role of planner/coordinator, seven with the role of teacher, and one each with the role of professional and communicator. Results suggested that teachers prefer that nurses apply their knowledge in the role of care provider.

As in Sadik's (1992) survey, providing specialized health care services received a low ranking in this study. $(\underline{M}=2.49)$. As a result of the passage of Public Law 94-142, the number of severely handicapped students mainstreamed into regular classrooms and the need to provide special services in schools is growing. It is likely that teachers will consider this service more important in the future. Four services were perceived as not important $(\underline{M}<2.0)$. Two services, community services and coordinating lunch programs, related to the role of planner/coordinator. Another service, health counseling to staff related to the roles of care provider and communicator. The last one of these services, recording attendance, did not relate to any role concepts. Two of these services, coordinating lunch programs and recording attendance, were also rated least important in Nehls' (1989), Sadik's (1992), Cassel's (1993), and Palmer's (1993) study. Another service, health counseling for staff, however, was considered important by Palmer's (1993) school nurses and ranked somewhat important $(\underline{M}=2.0-2.17)$ in other studies (Nehls, 1989; 
Sadik, 1992; and Cassel, 1993). Although consistently ranked low by teachers, in this researcher's experience teachers do consult the school nurse regarding health matters.

When considering the top five services rated most important in Sadik's (199.2) study, the role of care provider was most important. For the top five services in this survey, the roles of care provider and planner/coordinator were most and equally important.

However, in comparing the overall average means (M) of the role concepts, the role of communicator had the highest average mean in both:studies. The ability to communicate is an important component of nursing practice as the role of communication is central to all other nursing roles. In both studies, the role of care provider was second highest and role of planner and coordinator was third highest. In this study the role of within the profession and teacher ranked fourth and fifth, respectively, whereas the reverse was found in Sadik's (1992) study. None of the services related to the role of researcher.

\section{Limitations}

The convenience sample included teachers from only one school district. Participation by this type of sample is voluntary which increases the risk of bias (Lobiondo-Wood \& Haber, 1990, p. 272). Consequently, the results of this study may not be representative of the total population 
and, therefore, may not be generalizable to teachers in other school districts.

In addition, replies may reflect how the school nurse functions in reality rather than how the participant would like her to function. Also, responses may have been affected by other factors such as the subject's personal rapport and experiences with the school nurse.

Data collection by use of questionnaire may have been partially responsible for the low rate of return and may have led to bias. Another disadvantage of the use of a questionnaire is the chance of misinterpretation of questions resulting in inaccurate responses or skipping." The openended question served to compensate for the restrictive nature of the close-ended items of the tool.

Recommendations for Further Research

The information gathered from reviewing the literature and conducting this study suggests the following recommendations for further research:

1. Replication of this study in another school district to validate its findings.

2. Replication of this study in other states to gather national data for comparison.

3. Determine which services school nurses currently provide and how those services considered important can be given priority.

4. Comparison of results of studies conducted on the 
perception of the school nurse role by various groups. These various groups could include school nurses themselves, teachers (high school as well as elementary and junior high), principals, administrators, and students.

5. Revision of SNS Tool. Items 19 and 22 have consisteritly been ranked least important in this and previous studies (Nehls, 1989; Sadik, 1992; Cassel, 1993; Palmer, 1993) and could be eliminated from the tool. Also, the difficult to analyze open-ended question could be replaced by close-ended questions addressing frequently made comments in the current open-ended question. The teachers in this study frequently commented on the need for increased school nurse time, delegation of school nurse services (and its safety), and the need to decrease her clerical workload. Furthermore, when using the sNS Tool, one might specify in cover/consent letter or on top of questionnaire from which standpoint participants should respond; nursing services currently being provided, services the school nurse could provide considering time available to her, or services considered important for the school nurse to provide.

6. Add services relating to the role concept of researcher such as: keeping up to date with current research, applying findings to practice, researching community resources, and presenting research that updates practice.

7. Define emergency care as including first aid. A number of teachers suggested taking care of injured as an 
additional service. Apparently, teachers did not consider taking care of injuries as being part of emergency care. Recommendations for Schoöl Nursing Practice

The teachers participating in this study valued school nurse services. The need for these services is growing as many students face inadequate or no medical care, changing family structures, and deteriorating social conditions (Kozlak, 1992). Students are coming to school with complex health problems and, therefore, require more nursing attention and time. These factors combined with severe cutbacks in school nurse time make priority setting essential.

In an effort to save time and to make more efficient use of available time, the school nurse will have to delegate tasks to others whenever feasible. Clerical duties should be assigned to clerical staff. Special procedures such as intermittent clean catheterization and gastrostomy tube feedings can be taught to other staff members, aides, or volunteers and regularly observed by school nurses to ensure proper technique. For most effective use of time, school nurses should determine what the expectations of the school nurse are at a particular school and prioritize accordingly; schools and students have unique needs.

It is essential for school nurses to constantly update their professional knowledge and clinical/assessment skills. In addition, strong teaching and communication skills will 
be needed to facilitate the delegation process as well as to promote health and learning at school.

In light of the present reduced funding for school districts, school nurses must become more assertive and vocal in communicating their expertise to others. They must become more visible in the school setting and the community. Moreover, school nurses must demonstrate their cost effectiveness and their ability to improve the quality of life of their clients. Above all, school nurses must closely work with and support teachers. Collaboration between these professionals is vital to enabling our children to reach their potentials. 
REFERENCES 
References

American School Health Association School Nurse

Implementation Guide Committee. (1989). An

implementation guide to the standards of school nursing

practice. Pub. No. N005. Kent, OH: ASHA.

American Nurses Association. (1983). Standards of school nursing practice. Kansas City: Author.

Brajkovich, H. L., \& Madison, R. (1986). A California

school nurse credential survey. Journal of School Nursing, 56, 437-439.

Bryan, S. (1973). School nursing in transition. St. Louis: Mosby.

Burns, N., \& Grove, S. K. (1987). The practice of nursing research: Conduct, critique, and utilization. Philadelphia: Saunders.

Cassel, S. (1993). The school nurse role as perceived by parents. Unpublished master's thesis, San Jose State University, San Jose, CA.

Commission on Teacher Credentialing. (1988). Standards of program quality and effectiveness for developing and evaluating programs of professional school nurse preparation in California. Sacramento: state of $\mathrm{CA}$. Commission on Teacher Credentialing. (1989). Standards of program Quality and effectiveness for developing and evaluating programs of professional school nurse preparation in California. Sacramento: state of $C A$. 
Council on Scientific Affairs. (1990). Providing medical services through school-based health programs. Journal of School Nursing, 60, 87-91.

Edwards, L.H., \& Cowell, J.M. (1985). The "nurse" in school nursing. Journal of School Health, 55, 82-83. Ely, E. A., \& Crowell, S. B. (1987). Enriching professional preparation of school nurses through a health assessment course. Journal of School Health, 57, 124-126.

Feeg, V. D. (1991). Disappearing school nurse services: Metamorphosis or endangered species? Pediatric Nursing, $17,430,466$

Hamric, A. B., \& Spross, J. A. (1989). The clinical nurse specialist in theory and practice (2nd ed.).

Philadelphia: Saunders.

Hawes, M. (1989). School nursing in Norwich health authority. Health Visitor, 62, 351-352. Igoe, J. B., \& Ciordano, B. P. (1992). Expanding school health services to serve families in the 21 st century. Washington: American Nurses Publishing. Johnson-Russell, J., \& Anema, M. G. (1989). Physical assessment skills: A new dimension to traditional school nursing. School Nurse, $5(1), 14-22$.

Kozlak, L. A. (1992). Comprehensive school health programs: The challenge for school nurses. Journal of School Health, $62,475-477$. 
Lerner, J. (1989). Learning disabilities: Theories, diagnosis, and teaching strategies (5th ed.). Boston: Houghton Mifflin.

Liebow, P. R. (1984). The new-look nurse. Journal of Psychosocial Nursing, 22(3), 37-41.

LoBiondo-Wood, G., \& Haber, J. (1990). Nursing research: Methods, critical appraisal, and utilization (2nd ed.). St. Louis: Mosby.

Lucero, M. (1978). The school nurse role as perceived by teachers and administrators in a selected school district. Unplublished master's thesis, San Jose state University, San Jose, CA.

Marriner, A. (1971). Opinions of school nurses about the preparation and practice of school nurses. Journal of School Nursing, 56, 437-439.

MCNab, W. L., \& Canida, E. Y. (1980). The need for nurse educators. Journal of School Health, 50, 89-91. Miller, E., \& Hopp, J.W. (1988). Perceptions of school nursing by school districts. Journal of School Health, 58, 197-199.

Miller, J.S.A. (1990). Implications of role expansion for school nurse managers. Journal of School Health, $\underline{60}, 29-30$.

Nehls, D. (1989). Services at the secondary level expected by students, parents, and classroom faculty: A descriptive study. Unpublished master's thesis, San Jose State University, San Jose, CA. 
Oda, D. S. (1979). School nursing: Current observations and future projections. Journal of school Nursing. 29. $437-439$.

Oda, D. S. (1981). A viewpoint on school nursing. American Journal of Nursing, 81, 1677-1678.

Oda, D. S. (1991). The invisible nursing practice. Nursing outlook, 39(1), 26-29.

Palmer, E. (1993). School nurses' perceptions of the value of their services: A descriptive survey. Unpublished master's thesis, San Jose State University, San Jose, CA.

Quick. C. (1993). School nurses: Common hassles and uplifts. Unpublished master's thesis, San Jose state University, San Jose, CA.

Regan, P. A. (1976). A historical study of the school nurse role. Journal of School Health, 46, 518-521. Resnick, M. D., Blum, R. W., \& Hector, J. (1980). Adolescent perceptions of the school nurse. Journal of School Health, 50, 551-553.

Ridge, H. (1980). Future directions of school nursing. Journal of School Health, 50, 49. Sadik, N. (1992). The school nurse role as perceived by elementary and middle school teachers. Unpublished master's thesis, San Jose State University, San Jose, CA. Santora, D., \& Steiner, H. (1982). School nurses and powerlessness. Journal of School Health, 52, 428-431. 
Seidenberg, A. (1984). School nurses: Improve the reception and sharpen the image. Journal of School Health, 54, $363-365$.

Stone, L. J., \& Perry, C. L. (1990). United States: Perspectives in school health. Journal of School Health, $\underline{60}, 363-369$.

Thompson, J. (1989). School health services in the United States: A view from the United Kingdom. Journal of School Health, 59., 243-245.

Thurber, F., Berry, B., \& Cameron, M. E. (1991). The role of school nursing in the United States. Journal of Pediatric Health Care, $5,135-140$. White, D. H. (1985). A study of current school nurse practice activities. Journal of School Health, 55, 52-56.

Wold, S. J. (1980). School nurses as change agents: Controlling our destiny. Journal of School Health, 50, 595-596.

Wold, S. J. (1981). School nursing: A framework for practice. St. Louis: Mosby. Wold, S. J., \& Dagg, N. V. (1978). School nursing: A framework for practice. Journal of School Health, $\underline{48}, 111-114$.

Young, V., \& Epstein, K. (1991). Good health, good grades. Thrust for Educational Leadership, 20(4), 33-36. 
Young-Cureton, V., \& Epstein, K. (1991). School nursing: It's more than Bandaids for kids. California Nursing, $13(2), 20-22$.

Young, V., \& Quick, C. (1991, January). School nurses: Common hassles and uplifts. Paper presented at the 41 st Annual Conference of the California School Nurses Organization, Fresno, CA.

Zanga, J. R., \& Oda, D. S. (1987). School health services. Journal of School Health, 57, 413-416. 
APPENDIX A

Cover/Consent Letter 
Tro TSANOSE

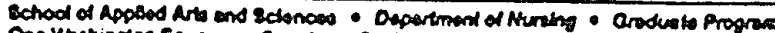

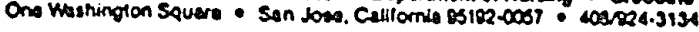

Cover letter/Consent Form

Dear Teacher:

You are invited to particlpate in a research study exploring

teachers. perceptions of the school nursa role. This study.

a Master's of science degree project at San Jose state

University, seeks to determine which components of the

school nurse role are valued most by educators.

Taking part in the otudy involves completion of a

questionnalre which should take less than 20 minutes.

Particlpation is voluntary and does not involve any risks

or benefits. You w111 not recelve any compensation for participating. If you decline to participate, it wili not afect your relations.with San Jose state University or your school district.

All aubjects will reasin anonymoua. The information you provide will be used for sclentific purposes only. It nay be published but in . Iorm in which you can never bo 1dentified. After completion of the tudy the results will be avallable to you upon requeat.

Any questione you way have about this study may be addressed to Dr. Virginia Young, (408) 924-3163. For questlons or concorns regarding subjocts' rights, you aay contact Dr. Serena Stanford, (408) 924-2480.

Completion and return of the questionnalre in the provided envelope (sealed) to your school nurse's mallbox within 5 days indicato your ullingness to participate voluntarily in this study. This letter 1 yourg to keep.

Thank you for your tiwe, Interest, and particlpation!

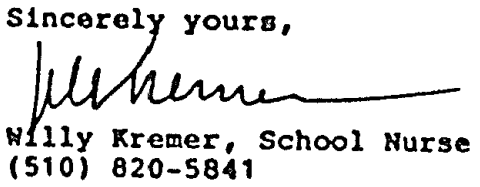


APPENDIX B

Questionnaire for study 
Das Educstor:

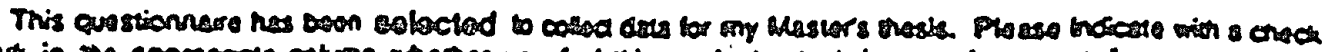

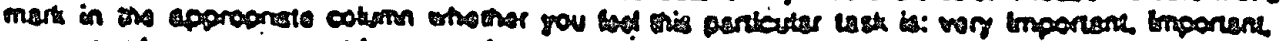

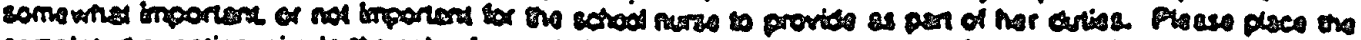

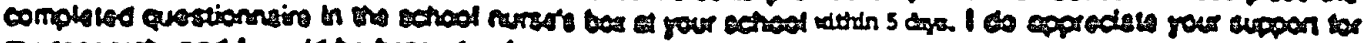

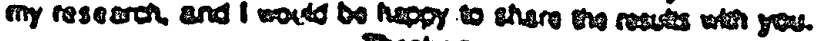

Theres you

H111y Rremar

\section{SCHOOL NURSE SERMCE DATA COLLETION TOOL}

\begin{tabular}{|c|c|c|c|c|}
\hline 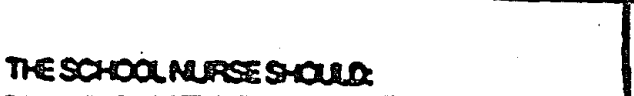 & Vory & moorisan & Eomomitas & Mea \\
\hline 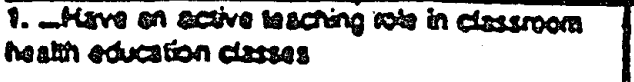 & & & & \\
\hline 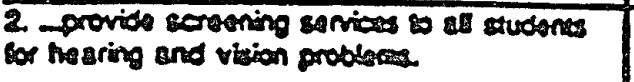 & & & & \\
\hline 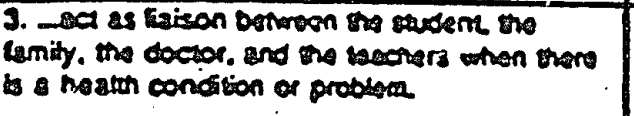 & & & & \\
\hline 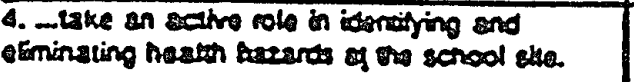 & & & & \\
\hline 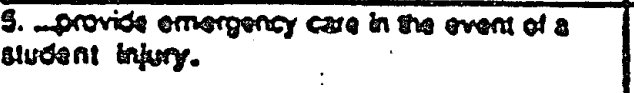 & & & & \\
\hline 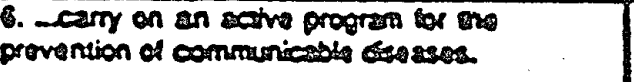 & & & & \\
\hline 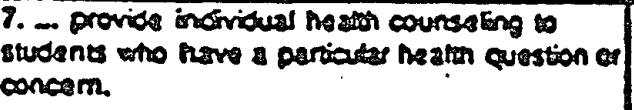 & & & & \\
\hline 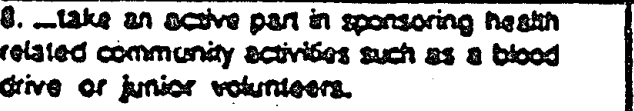 & & & & \\
\hline 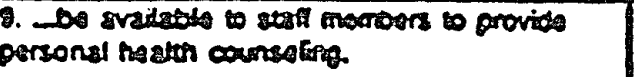 & & & & \\
\hline 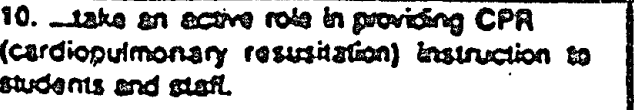 & & & & \\
\hline 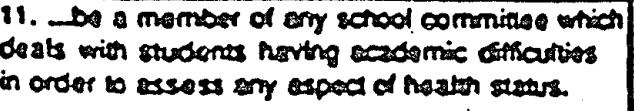 & & & & $\cdot$ \\
\hline
\end{tabular}




\begin{tabular}{|c|c|c|c|c|}
\hline & Vory. & mportart & $\begin{array}{c}\text { Somomes } \\
\text { importand }\end{array}$ & thoortant \\
\hline 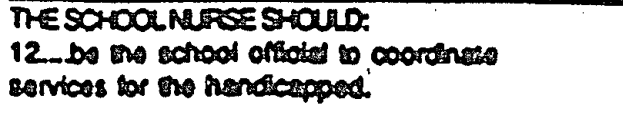 & & & &. \\
\hline \multicolumn{5}{|l|}{ 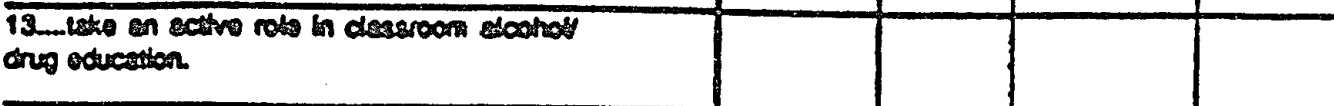 } \\
\hline \multicolumn{5}{|l|}{ 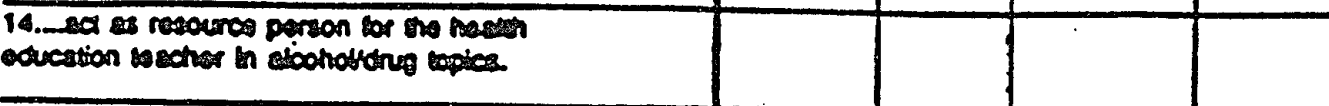 } \\
\hline \multicolumn{5}{|l|}{ 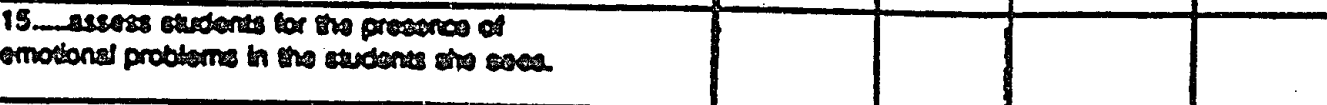 } \\
\hline \multicolumn{5}{|l|}{ 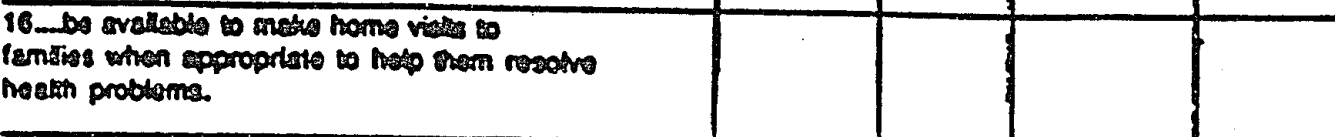 } \\
\hline \multicolumn{5}{|l|}{ 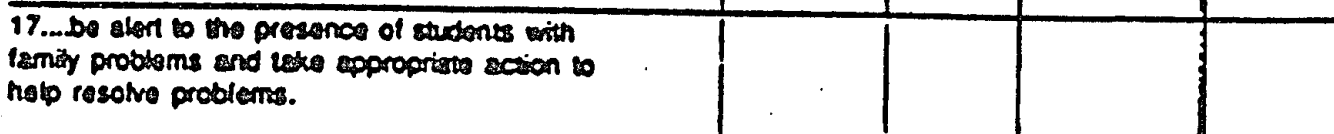 } \\
\hline \multicolumn{5}{|l|}{ 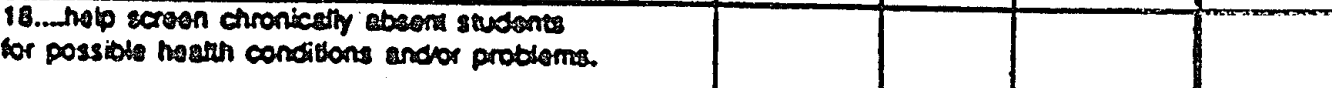 } \\
\hline \multicolumn{5}{|l|}{$\begin{array}{l}\text { 19...participale in the recording of deity } \\
\text { studerd attendancos for the school }\end{array}$} \\
\hline \multicolumn{5}{|l|}{ 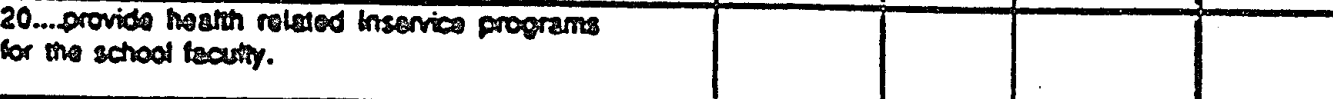 } \\
\hline \multicolumn{5}{|l|}{ 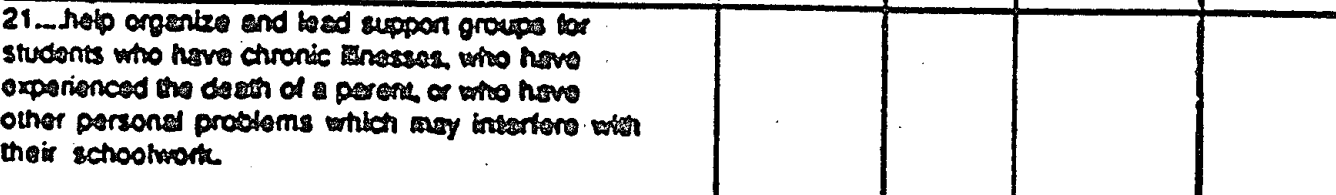 } \\
\hline \multicolumn{5}{|l|}{ 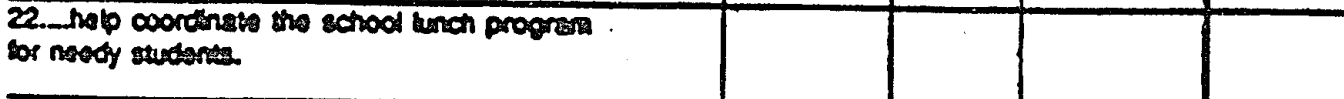 } \\
\hline \multicolumn{5}{|l|}{ 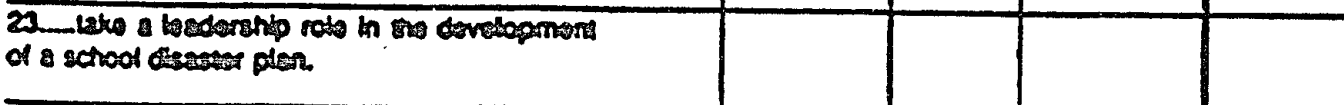 } \\
\hline \multicolumn{5}{|l|}{ 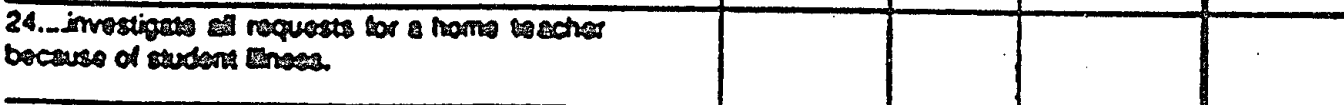 } \\
\hline \multicolumn{5}{|l|}{ 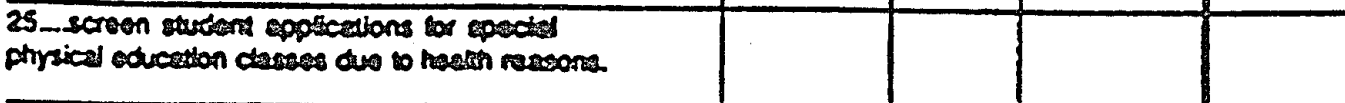 } \\
\hline 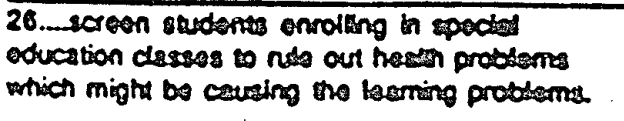 & & & & \\
\hline
\end{tabular}




\begin{tabular}{|c|c|c|c|c|}
\hline & $\begin{array}{l}\text { Vory } \\
\text { imporisnil }\end{array}$ & Imporiant & $\begin{array}{l}\text { Somewnat } \\
\text { imporsant }\end{array}$ & $\begin{array}{c}\text { Nol } \\
\text { imponani }\end{array}$ \\
\hline \multicolumn{5}{|l|}{ 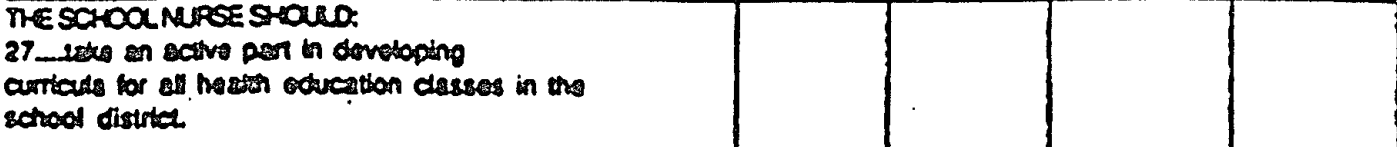 } \\
\hline \multicolumn{5}{|l|}{$\begin{array}{l}\text { 28. provide hosth rolated insorvico progrems } \\
\text { tor perents. }\end{array}$} \\
\hline \multicolumn{5}{|l|}{$\begin{array}{l}\text { 29. assess overy students immunization slatus. } \\
\text { to mete cure immunications are up to dets. }\end{array}$} \\
\hline \multicolumn{5}{|l|}{ 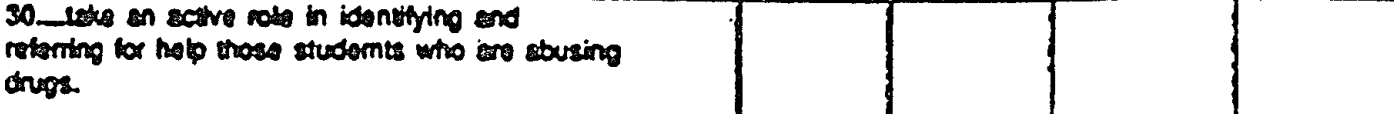 } \\
\hline \multicolumn{5}{|l|}{$\begin{array}{l}\text { 31._establish and maintain first aid policios } \\
\text { and procedures for the ectrool. }\end{array}$} \\
\hline \multicolumn{5}{|l|}{$\begin{array}{l}\text { 32. provide inservice on basic first gid } \\
\text { procoduros } 10 \text { as many school staft as possibta. }\end{array}$} \\
\hline \multicolumn{5}{|l|}{ 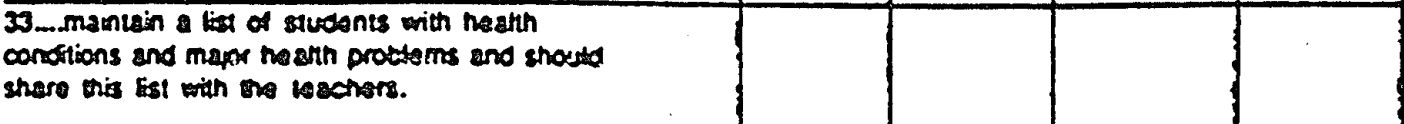 } \\
\hline \multicolumn{5}{|l|}{ 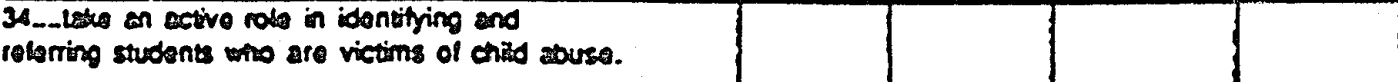 } \\
\hline \multicolumn{5}{|l|}{ 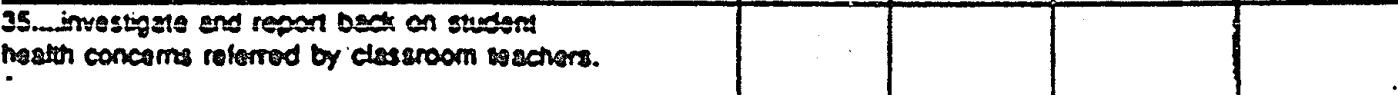 } \\
\hline \multicolumn{5}{|l|}{ 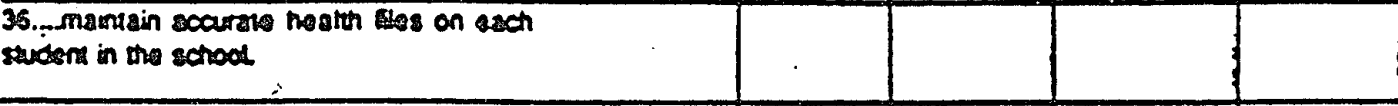 } \\
\hline \multicolumn{5}{|l|}{$\begin{array}{l}\text { 37. provide routina inmunteations to sludents } \\
\text { otro ned then. }\end{array}$} \\
\hline \multicolumn{5}{|l|}{ 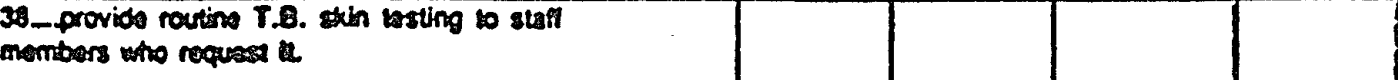 } \\
\hline \multicolumn{5}{|l|}{ 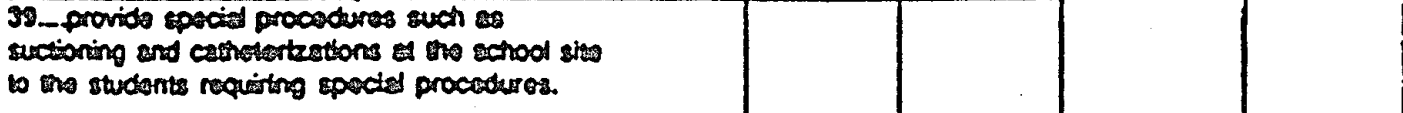 } \\
\hline \multicolumn{5}{|l|}{ 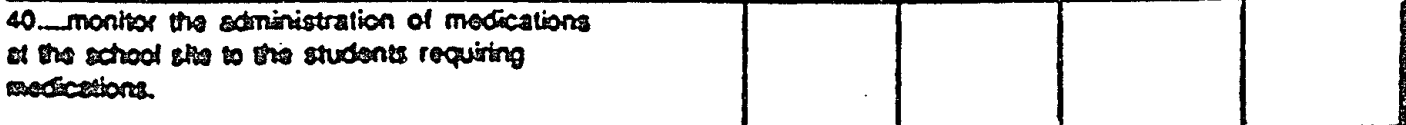 } \\
\hline \multicolumn{5}{|l|}{ 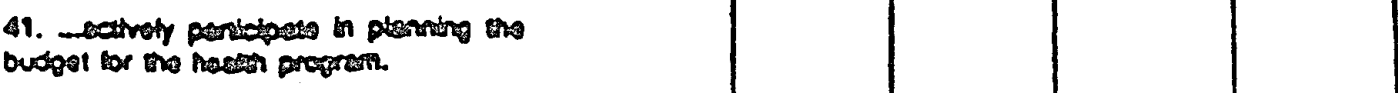 } \\
\hline 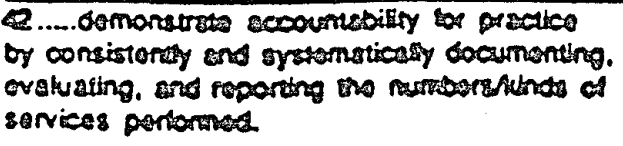 & & & & \\
\hline
\end{tabular}




\begin{tabular}{|c|c|c|c|c|}
\hline & $\begin{array}{l}\text { Vory } \\
\text { bmonert }\end{array}$ & imporiant & $\begin{array}{l}\text { Somswnat } \\
\text { imponent }\end{array}$ & imporaments \\
\hline 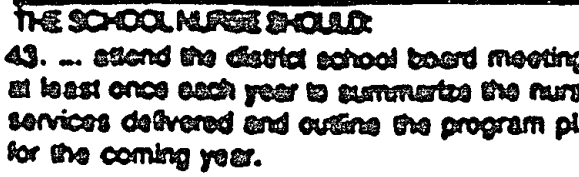 & . & & & \\
\hline 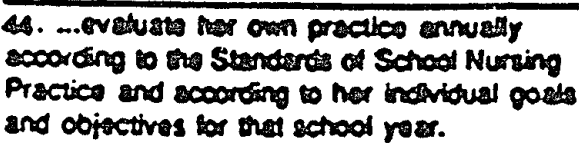 & & & & \\
\hline
\end{tabular}

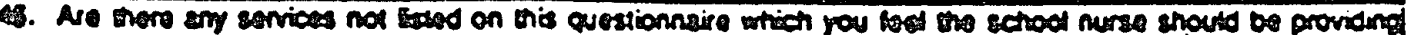
to the schoor? Plases est hom.

1.

2.

3.

A. What grado of gredis do you best?

Prate 1 r 2

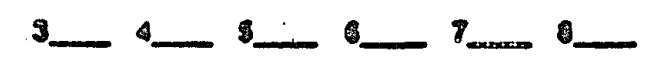

ㅇ. Sosciat ed

Rogutar Ed

Ono

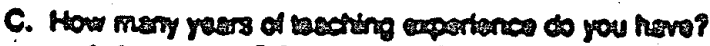

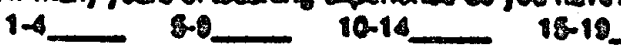

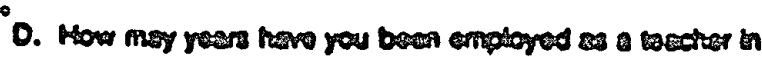
$8-4$
80.
10.14
1810

$30+$

E Your 20-30

503

4049

F. Your conceso

Forado

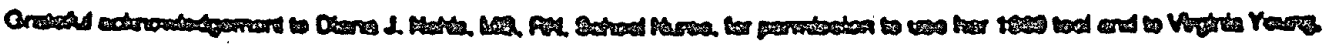

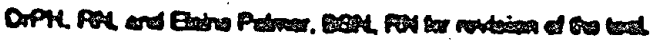




\section{APPENDIX C \\ Permission Letters for Use of Questionnaire}


May 20. 1991

Virgin la Young. Or. Ph.. R.N.

Assoclate Professor

San lose State University

Department of Nursing

San Jose. CA 95192-0057

Dear Dr. Young

I an del ighted to give permission to you and to your students at San jose State University to make use of the research tool I teveloped. the School Nurse Services (SNS) Data Collection Tool. and which was subsequently revised. I hope the research for which it is used proves valuable in the advancement of the school nurse profession.

I would like to recelve a copy of the results of any studies for which the SAS Data Collection Tol or the revised format is used. It may be malled to me at the address below.

Best wishes.

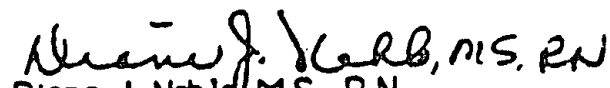

Diana J. Neh ish M.S.. R.N.

1004 Leland Drive

Lafayette. Ca 94549

(415) $938-2492$ 
101 Malmedy Road

Fort Ord. CA $93941-1512$

May 3. 1991

Dr. Virginia Young

School Nurse Program Coordinator

Department of Nursing

San Jose State University

san Jose. CA 95192-0057

Dear Dr. Young and San Jose State Graduate Nursing Colleagues:

This letter gives my wrieten peraission to Dr. Virginia Young and San Jose state graduate nurging studento (at or. Young's discretionl to use, adapt, and revise the School Nurse Service Data Collection Tool of 1991. The School Nurse Service Data collection Tool was originally developed by Diana $J$. Nehls for her 1989 research. With $\mathrm{As}$. Nehls' uritten permission. Dr. Young and I adapted and revised Nehls' 1989 Tool to collect my research data at the lst Annual California school Nurses. Conference in 1991.

After using the 1991 rool and attempting to analyze wy data. I have several recommendations. First. question 49 would be more definitive if participants vere asked to rank order the eight wost important services. Second, the trite-in question 50 prompted school nurses to give many categories of responses in addition to services. Coding thege responses has been difficult at best. If asked as open-ended questions. 49 and 50 could potentially generate enough qualitative data for a thesis! Third, according to the data I have analyzed. a few iraportant school nursing services are not encompassed by or specified on the Tool (1991). Consequently. I would revise the rool (1991) before I would use it again.

If you use the School Nurse Service Cata Collection Tool. I would appreciate recedving a brief summary or abstract of your completed research findings. As of June 1.1991. ay new address will be: 10727 Armstrong North, Clovis, CA 93612. I wish you much success in your research efforts.

Yours truly,

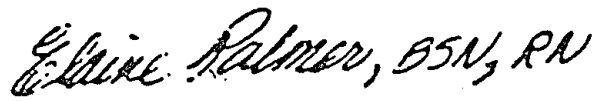

Elaine Palmer. BSN, RN (209) $323-8189$

-c suisinge Cassel 


\section{APPENDIX D \\ San Jose State University \\ Institutional Review Board Approval}


TSONJOSE

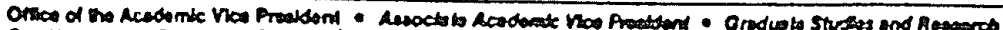

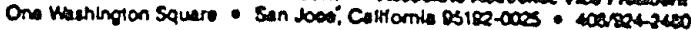

To: W11ly Rremer

252 Balcota Ct.

Danv111e, CA 94526

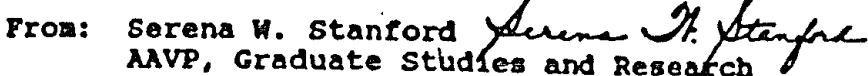

Dato: March 9, 1993

The Human Subjects-Institutional Revlew Board has reviewed and approved your request for exemption from human subjects Review for the proposed study entitled: "The School Nurse Role a Percelved by Elementary
and Hiddle School Teachers"

Provided that there are no changes in the procedure proposed, you may proceed with this study without further review by the Human Subjects-Institutional Review Board. You wust notify the Buman Subjects-Institutional Review Board of any changes in the subject population or procedure for this study

I do caution you, however, that Federal and state statutes and University policy require investigators conducting research under exempt categorles to be knouledgeable of and comply with Federal and state regulations for the protection of human aubjects in research. This includos providing necessary information to enable people to make on informed decision regarding particlpation in your study. rurther, whenever people participate in your research as human cubjects, they should be appropriately protected from risk. This includes the protection of the confldentiality of all data that may be collocted from the subjects. If at any tiro a subject becomes infured or complains of infury, you must notify Dr. Serena stanford immediately. Injury includes but is not iinited to bodily hara, psychological trauss and release of potentially damaging personal information.

If you have questions, please contact ae at 408-924-2480.

CC: Ginny young 
19. TAN SAOSE

II

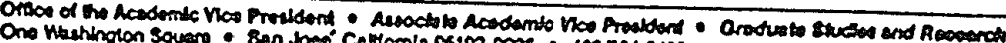

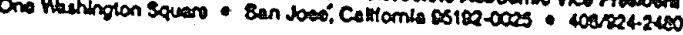

To: H112y Rremor

252 Balceta $c t$.

Danv1lio, Ca 94526

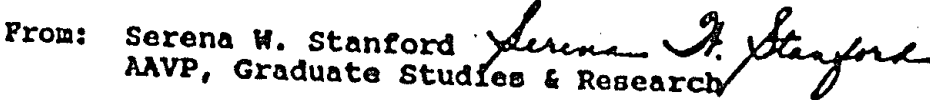

Date: Apr11 14, 1993

This letter acknowledges that the human subjectsInstitutional Revlew Board has recelved and approved the changes to your proposed study entitled:

"The School Nurse Rolo as Percelved by

Elementary and Middle school Teacherg"

1. The titlo of the profecte has been changed to read:

"The School Nurse Rolo

Junior High School Teacherg"

by Elementary and

If you have any questions, please contact we at 408-924- 


\section{APPENDIX E \\ Agency Consent Letter}




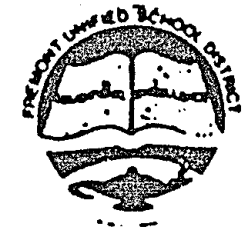

\section{FREMONT UNIFIED SCHOOL DISTRICT}

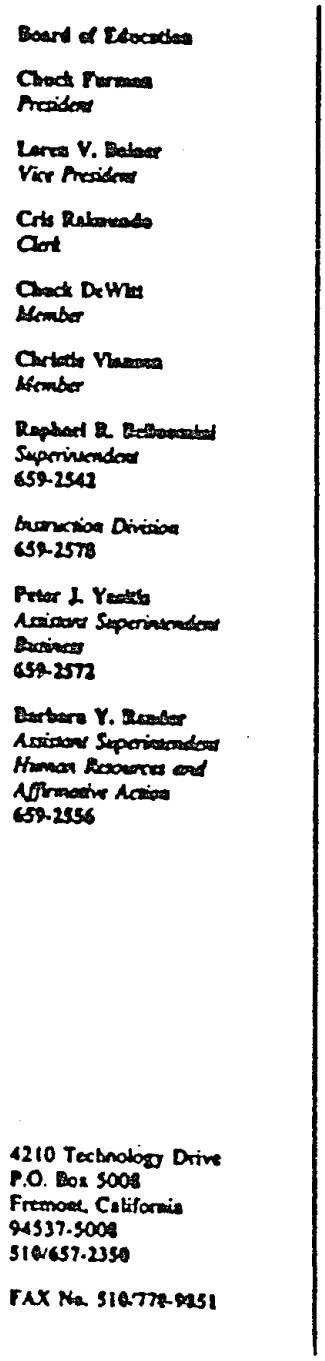

Hs. Hiliy Kremer

252 Balceta Court

Danvilie. Californta 94526

Dear Hs. Kremer:

Th1s is to serve as uritten approval for you to conduct, as part of the requirements for your Master of Sclence degree frow San Jose State University, survey with the Fremont Unifled School olstrict investigating teachers' perceptions of the school nurse role. The survey will be of elementury and juntor high teachers and the school nurses in our diserict may assist as needed.

Ke would appreclate receiving a copy of the results of your survey when completed.

Very truly yours.

Withdoratheres

HILLIAA HALKER, Coordinator

Pupll Services

H:tho 